\title{
Increased resistance of Escherichia coli 0157:H7 to electron beam following repetitive irradiation at sub-lethal doses and an analysis of genes of Escherichia coli resistance
}

Leah Levanduski

West Virginia University

Follow this and additional works at: https://researchrepository.wvu.edu/etd

\author{
Recommended Citation \\ Levanduski, Leah, "Increased resistance of Escherichia coli 0157:H7 to electron beam following repetitive \\ irradiation at sub-lethal doses and an analysis of genes of Escherichia coli resistance" (2007). Graduate \\ Theses, Dissertations, and Problem Reports. 2561. \\ https://researchrepository.wvu.edu/etd/2561
}

This Thesis is protected by copyright and/or related rights. It has been brought to you by the The Research Repository @ WVU with permission from the rights-holder(s). You are free to use this Thesis in any way that is permitted by the copyright and related rights legislation that applies to your use. For other uses you must obtain permission from the rights-holder(s) directly, unless additional rights are indicated by a Creative Commons license in the record and/ or on the work itself. This Thesis has been accepted for inclusion in WVU Graduate Theses, Dissertations, and Problem Reports collection by an authorized administrator of The Research Repository @ WVU. For more information, please contact researchrepository@mail.wvu.edu. 


\title{
Increased Resistance of Escherichia coli O157:H7 to Electron Beam
} Following Repetitive Irradiation at Sub-lethal Doses and an Analysis of Genes of Escherichia coli Resistance

\author{
Leah Levanduski
}

Thesis submitted to the College of Agriculture, Forestry and Consumer Sciences

at West Virginia University in partial fulfillment of the requirements for the degree of

Master of Science

In

Food Microbiology

\author{
Jacek Jaczynski, Ph.D., Chair \\ Jianbo Yao, Ph.D. \\ Kristen Matak, Ph.D.
}

Department of Animal and Nutritional Sciences

\author{
Morgantown, West Virginia \\ 2007
}

Key words: Escherichia coli O157:H7, electron beam, inactivation kinetics, $\mathrm{D}_{10}$-value, non-thermal food preservation, micro-array

Copyright 2007 Leah Levanduski 


\section{ABSTRACT \\ Increased Resistance of Escherichia coli O157:H7 to Electron Beam Following Repetitive Irradiation at Sub-lethal Doses and an Analysis of Genes of Escherichia coli Resistance}

\section{Leah Levanduski}

One way that food processors in the United States control food-borne pathogens in a non-thermal manner is with the application of electron beam (e-beam) radiation. Increased resistance of Escherichia coli $\mathrm{O} 157: \mathrm{H} 7$ to various stressors such as $\mathrm{pH}$, temperature, ionic strength, and antibiotics has been demonstrated; therefore, the objective of this study was to determine if the $\mathrm{D}_{10}$-value for E. coli $\mathrm{O} 157: \mathrm{H} 7$ (E. coli) in ground beef increases due to repetitive exposure to e-beam at sub-lethal levels. Ground beef samples were inoculated with an ATCC strain of E. coli and incubated to approximately $10^{9} \mathrm{CFU} / \mathrm{g}$ followed by e-beam processing. Survivors were enumerated using a standard spread-plating technique. Colonies of E. coli survivors from the highest e-beam dose were isolated and grown for the next cycle of inoculation in ground beef and e-beam processing. Four such consecutive cycles of isolation and e-beam processing were performed. The $\mathrm{D}_{10}$-values for E. coli survivors following each cycle of e-beam processing were calculated from survivor curves. The $\mathrm{D}_{10}$-values increased (P $<0.05$ ) with each subsequent cycle of e-beam processing, starting at $0.24 \pm 0.03 \mathrm{kGy}$ for E. coli ATCC strain 35150 and reaching $0.63 \pm 0.02 \mathrm{kGy}$ for E. coli isolate L3, which is the result of three cycles of e-beam exposure. Following four cycles of e-beam processing, radio-resistance increased for isolate L4 $(\mathrm{P}<0.05)$, resulting in the survival of this strain to an e-beam dose of $3.0 \mathrm{kGy}$. The data demonstrates that e-beam can efficiently inactivate E. coli in food products; however, the organism demonstrated increased resistance when repeatedly subjected to sublethal e-beam processing. Although the exact mechanism of increased radio-resistance of $E$. coli to e-beam is unclear at the moment, based on the available literature regarding increased resistance of E. coli to various stressors, it is likely that some genetic mechanism is involved. Therefore, we are currently investigating this hypothesis through genome-wide expression analysis using micro-array technology. 


\section{Table of Contents}

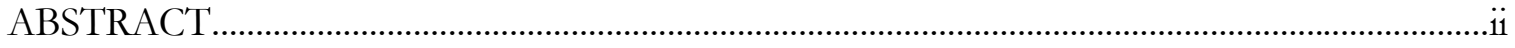

Table of Contents ....................................................................................................................iii Increased Resistance of Escherichia coli O157:H7 to Electron Beam Following Repetitive Irradiation at Sub-lethal Doses............................................................................................................ 1

INTRODUCTION ………………………………………………………………….... 1

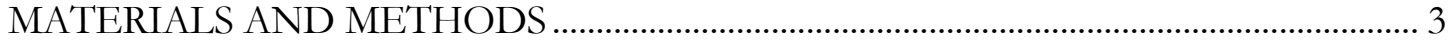

Sample preparation ……………………………………………………………………. 3

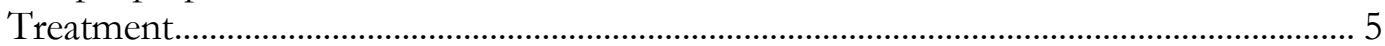

Bacterial enumeration of E. coli survivors ……………………………………………….... 6

Isolation of E. coli survivors for repetitive e-beam processing............................................. 6

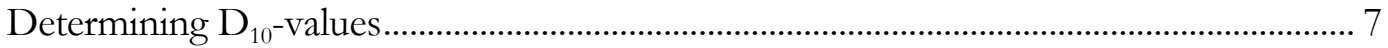

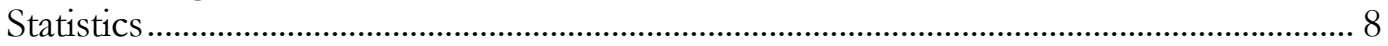

RESULTS AND DISCUSSION ………………………………………………………. 8

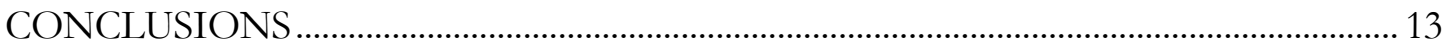

ACKNOWLEDGEMENTS.............................................................................................. 14

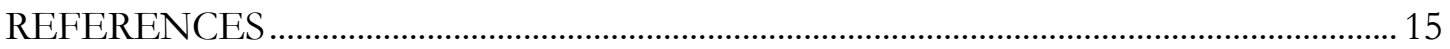

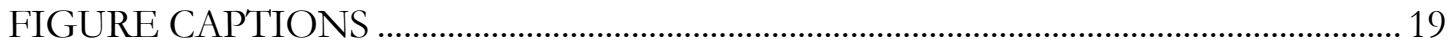

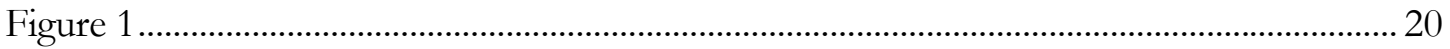

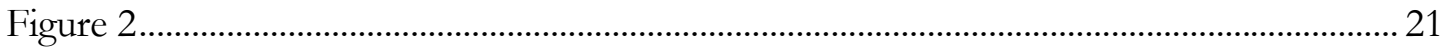

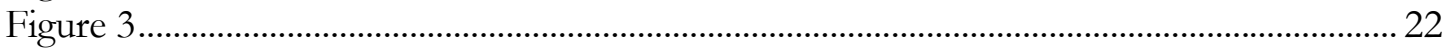

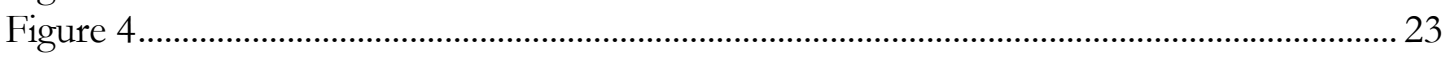

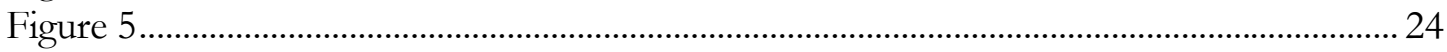

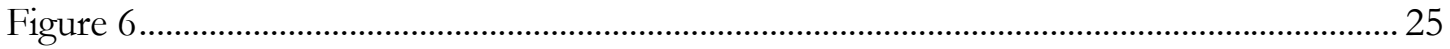

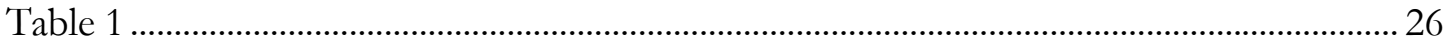

An Analysis of Genes of Escherichia coli Resistance.....................................................................2 27

INTRODUCTION ……………………………………………………………………….... 27

MATERIALS \& METHODS …………………………………………………………….... 34

Isolation of Strains .............................................................................................................. 34

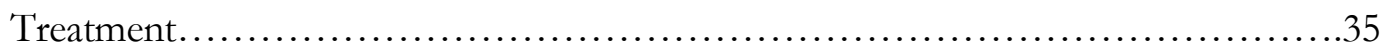

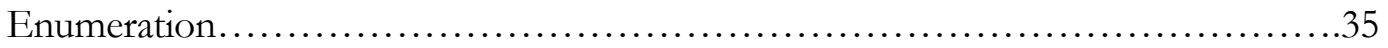

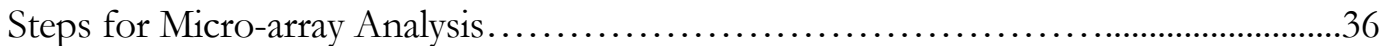

RESULTS \& DISCUSSION ……………………………………………………………........ 37

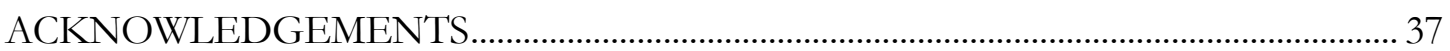

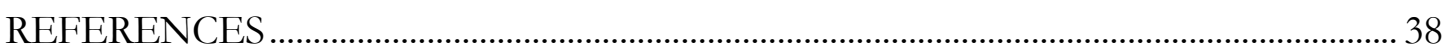

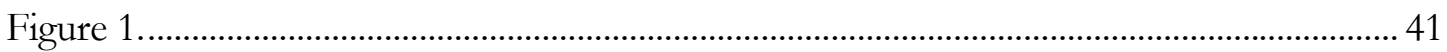

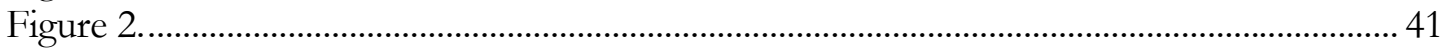

APPENDIX A: STEPS FOR MICROARRAY ANALYSIS ………………………………... 43 


\section{Increased Resistance of Escherichia coli O157:H7 to Electron Beam Following Repetitive Irradiation at Sub-lethal Doses}

\section{INTRODUCTION}

Food-borne illness caused by the ingestion of food contaminated with Escherichia coli O157:H7 has been a growing problem in the United States since a meat-borne outbreak in 1982 (Jay et al., 2005). In 1997, a U.S. company voluntarily recalled almost 11.5 million $\mathrm{kg}$ of ground beef after 20 illnesses had been associated with meat contaminated with E. coli O157:H7 in Colorado. In 2002, there were 36 food recalls in the U.S. due to E. coli O157:H7 contamination. All 36 recalls involved ground beef products. Individual recalls ranged in size from almost 9 to 19 million $\mathrm{kg}$. In 1999, there were 62,458 confirmed cases of food-borne illnesses due to E. coli O157:H7, resulting in 1,843 hospitalizations and 52 deaths accounting for 0.7 billion dollars in estimated cost. Recently, a multi-state outbreak of E. coli O157:H7 in the United States implicating contaminated spinach and later lettuce was responsible for over 190 illnesses and 3 confirmed deaths (U.S. Food and Drug Administration, 2006).

Escherichia coli is a normal inhabitant of the digestive tract of both humans and animals and most strains are generally considered harmless (Bell and Kyriakides, 1998). However, ingestion of even low numbers of serotype O157:H7 may cause hemorrhagic colitis (HC) and hemolytic uremic syndrome (HUS), which may result in renal failure and death (WHO, 2007).

One method used as a means to non-thermally inactivate E. coli O157:H7 in food products is electron beam (e-beam) irradiation (Urbain, 1986). This technology utilizes a stream of highenergy electrons generated by a linear accelerator to directly damage the microbial DNA by introducing cross-linkages, thus rendering microorganisms unable to grow and reproduce (Tauxe, 2001). However, available water in food (i.e., water activity) also plays a critical role in microbial inactivation, contributing to microbial death as an indirect effect due to water 
radiolysis (Black and Jaczynski, 2006). Tauxe (2001) has estimated that if 50\% of meat and poultry food products were irradiated, an estimated 23,000 cases, 700 hospitalizations, and 20 deaths caused by E. coli could be prevented annually. According to the U.S. Department of Agriculture, the current maximum allowable dose of radiation is 4.5 kiloGrays (kGy) for refrigerated meat and 7.0 kGy for frozen meat products (U.S. Department of Agriculture, 1999).

Microbial adaptation and increased microbial resistance has been shown to occur under conditions previously thought to prevent microbial growth, such as low $\mathrm{pH}$, high temperature, and antibiotics (Benjamin and Datta, 1995; Yuk and Marshall, 2003; Schroeder et al., 2002; Yuk and Marshall, 2004). Acidic foods previously thought to be safe from pathogens have been implicated in outbreaks due to E. coli O157:H7. For example, in 1996 three outbreaks due to contamination of apple cider with E. coli O157:H7 resulted in 66 illnesses and 1 death (Centers for Disease Control and Prevention, 1997).

E. coli has the capability of developing an increased acid resistance if the cells have been pre-incubated at sub-lethally low $\mathrm{pH}$, such as 2.5-2.0 (Benjamin and Datta, 1995; Lin et al., 1996). Furthermore, increased acid resistance of E. coli also results in cross-protection against other stressors such as ionizing radiation, heat, salt (i.e., ionic strength), and lactoperoxidase system (Leyer et al., 1995; Buchanan et al., 1999). A similar development of increased microbial resistance to antibiotics resulting in a cross-protection against e-beam was reported for nalidixic acid resistant Salmonella enterica subsp. enterica serotype Montevideo (James et al., 2007). Black and Jaczynski (2007a) found that pre-incubation of E. coli O157:H7 under sub-lethally high ionic strength (i.e., salt content) in meat food products induces crossprotection, resulting in increased radio-resistance to e-beam. Yuk and Marshall (2003) demonstrated that pre-incubation of E. coli $\mathrm{O} 157: \mathrm{H} 7$ at sub-lethally high temperatures $\left(45^{\circ} \mathrm{C}\right)$ 
results in heat-adaptation and consequently, increased $\mathrm{D}_{10}$-value. The development of heat adaptation was also accompanied by changes in membrane lipid composition that could potentially affect verotoxin production.

It appears, therefore, that E. coli $\mathrm{O} 157: \mathrm{H} 7$ has the capability to develop increased resistance to a variety of stressors commonly used in food to prevent microbial growth or to inactivate the pathogens. It is likely that E. coli $\mathrm{O} 157: \mathrm{H} 7$ may also develop increased radioresistance to e-beam. Increasing the use of e-beam radiation provides a greater chance of repetitive exposure of enterohemorrhagic strains like O157:H7 to this form of radiation. Given the 20-minute generation time of E. coli under optimal conditions in food such as meat products, E. coli $\mathrm{O} 157: \mathrm{H} 7$ could develop an increased radio-resistance due to repetitive exposure to e-beam at sub-lethal doses.

To our knowledge there have been no published reports in literature regarding development of an increased radio-resistance of E. coli O157:H7 in food to e-beam radiation. The objective of this study was to determine if the $\mathrm{D}_{10}$-value for E. coli $\mathrm{O} 157: \mathrm{H} 7$ inoculated in ground beef increases following repetitive exposure to e-beam radiation at sub-lethal levels.

\section{MATERIALS AND METHODS}

\section{Sample preparation}

Lean ground beef was purchased from a local grocery store, vacuum packaged, and stored at $-80^{\circ} \mathrm{C}$ until needed. Preliminary tests confirmed that the total coliform counts in the ground beef sample were below detectable levels. Escherichia coli O157:H7 ATCC strain 35150 (hereafter called E. coli) was used in our experiments. E. coli lyfo-disks were reconstituted by crushing one pellet using a sterile spatula in $0.5 \mathrm{ml}$ of sterile trypticase soy broth (TSB) (Becton, Dickinson, and Company, Sparks, MD). The content was then aseptically transferred 
to $10 \mathrm{~mL}$ of sterile TSB and allowed to grow at $35^{\circ} \mathrm{C}$ for $24 \mathrm{hr}$ in an incubator/shaker set at 150 rpm (C24 Incubator/Shaker, New Brunswick Scientific, Edison, NJ). A 2 mL aliquot of the E. coli culture was aseptically transferred to $38 \mathrm{~mL}$ of sterile TSB and allowed to grow at $35^{\circ} \mathrm{C}$ for $7 \mathrm{hr}$ in the incubator/shaker set at $150 \mathrm{rpm}$. Preliminary studies (data not shown) confirmed that this procedure yielded an E. coli culture at stationary phase of growth.

The 7-hr E. coli culture was used as an inoculum for ground beef. Prior to inoculation, the ground beef sample was thawed overnight in a refrigerator and the inoculum was added at $5 \%$ to a thawed sample of ground beef. Following inoculation, the ground beef sample was incubated (Isotemp Incubator, Fisher Scientific, Pittsburgh, PA) at $35{ }^{\circ} \mathrm{C}$ for $30 \mathrm{hr}$. Preliminary studies (data not shown) verified that this procedure resulted in a concentration of E. coli at approximately $10^{9} \mathrm{CFU} / \mathrm{g}$ of ground beef. Distilled and de-ionized water $\left(\mathrm{ddH}_{2} \mathrm{O}\right)$ was periodically added to account for moisture loss during incubation and the sample was periodically mixed manually in order to ensure adequate distribution of microbial cells in the meat sample.

Following incubation, 18 individual samples of approximately $12 \mathrm{~g}$ of inoculated beef were separately packed (Kapak SealPAK pouches, Kapak Corporation, Minneapolis, MN) and aerobically sealed (Kapak sealer, Kapak Corporation, Minneapolis, MN). Each sample was spread evenly, resulting in a thickness of less than $1 \mathrm{~mm}$ in order to ensure complete penetration of e-beam and even distribution of absorbed dose throughout the sample (Jaczynski and Park, 2003). The samples were stored at $-80^{\circ} \mathrm{C}$ until shipment.

Following incubation and prior to the packing of the ground beef samples, water activity $\left(\mathrm{A}_{\mathrm{w}}\right.$ ), ionic strength (IS), and $\mathrm{pH}$ were measured using a $\mathrm{A}_{\mathrm{w}}$ meter (Hygrolab 3, Rotronic Instrument Corp., Huntington, NY), conductivity meter (AB30, Fisher Scientific, Pittsburgh, PA), and pH meter (AB15, Fisher Scientific, Fair Lawn, NJ), respectively. The IS 
was defined as an equivalent molar (M) concentration of $\mathrm{NaCl}$ and the IS was determined by comparing the conductivity of a meat sample to a standard curve constructed with $\mathrm{NaCl}$. The IS was expressed as an equivalent $\% \mathrm{NaCl}$. The $\mathrm{A}_{\mathrm{w}}$, IS, and $\mathrm{pH}$ of a food matrix in which the microorganisms are inactivated may affect microbial radio-resistance to e-beam and hence, could have a confounding effect on the $\mathrm{D}_{10}$-values determined in our experiments (Black and Jaczynski, 2007a; Black and Jaczynski, 2007b; James et al., 2007). The optimum $A_{w}$, IS, and $\mathrm{pH}$ of E. coli are 6-7, $0 \%$ and 0.995 , respectively (The International Commission on Microbiological Specifications for Foods, 1996). Therefore, we controlled for these factors in the inoculated ground beef samples in order to minimize their effects on the D-value in our experiment. At least six $\mathrm{A}_{\mathrm{w}}$, IS, and $\mathrm{pH}$ measurements were taken and the results are reported as mean values of $1.00,0 \%$, and 5.5-6.0, respectively.

\section{Treatment}

Samples were packed and shipped according to an approved institutional protocol in a heavy-duty styrofoam cooler filled with dry ice. Samples were shipped overnight to an e-beam processing facility (Sterigenics International, San Diego, CA). At the e-beam facility, the samples were allowed to equilibrate to $4^{\circ} \mathrm{C}$ overnight in a refrigerator prior to e-beam processing. The samples at refrigeration temperature $\left(4^{\circ} \mathrm{C}\right)$ were subjected to one-sided ebeam with energy fixed at $10 \mathrm{MeV}$ and the following doses were applied - 0 (control), 0.5, 1.0, 1.5, 2.0, and $2.5 \mathrm{kGy}$. The applied e-beam doses were confirmed with film dosimetry (Jaczynski and Park, 2003).

Immediately following the e-beam treatment, samples were frozen, packed, and shipped overnight back to the Food Microbiology laboratory at West Virginia University (WVU). Upon arrival at WVU, the e-beam processed samples were stored at $-80^{\circ} \mathrm{C}$ until 
analysis. Preliminary studies (data not shown) determined that the freeze-thaw cycles in our experiments did not $(\mathrm{P}>0.05)$ affect the E. coli survival and therefore, did not confound our results. Three separate e-beam experiments $(n=3)$ were conducted for a total of 18 samples (six e-beam doses).

\section{Bacterial enumeration of E. coli survivors}

The samples were equilibrated to $4^{\circ} \mathrm{C}$ overnight in a refrigerator prior to enumeration. Each sample was enumerated by aseptically placing $10 \mathrm{~g}$ of the e-beam processed sample using a sterile spatula into a sterile filter stomacher bag (Two-Chamber Filter Bag, Fisher Scientific, Pittsburgh, PA). An aliquot of $90 \mathrm{ml}$ of dilutent (Butterfield phosphate buffer, Hardy Diagnostics, Santa Maria, CA) was aseptically added to the filter stomacher bag and the bag was placed into a stomacher (Bag Mixer 400, Interscience, St. Nom, France) set at medium speed for $2 \mathrm{~min}$. Further serial dilutions were aseptically made by taking $10 \mathrm{ml}$ of diluted sample and transferring it into a $90 \mathrm{ml}$ diluent bottle, followed by shaking the bottle to uniformly distribute survivors. An aliquot of $1 \mathrm{ml}$ of each serial dilution was pipetted onto a petrifilm plate (Petrifilm E. coli/Coliform Count Plate, 3M, St. Paul, MN) and spread by a petrifilm spreader. Plates were incubated at $35^{\circ} \mathrm{C}$ for $48 \mathrm{hr}$ using AOAC method 991.14. Only plates with 15-150 colonies were counted. All bacterial enumerations were performed in duplicate and the mean values are reported as $\mathrm{CFU} / \mathrm{g}$.

Isolation of E. coli survivors for repetitive e-beam processing

Following the 48-hr incubation of the petrifilm plates, colonies of E. coli survivors from the highest e-beam dose were randomly isolated from the plates using aseptic techniques and incubated in $10 \mathrm{~mL}$ of sterile $\mathrm{TSB}$ at $35^{\circ} \mathrm{C}$ for $24 \mathrm{hr}$ in an incubator/shaker set at $150 \mathrm{rpm}$. A $2 \mathrm{~mL}$ aliquot of the resultant E. coli culture was aseptically added to $38 \mathrm{~mL}$ of sterile TSB 
and incubated at $35^{\circ} \mathrm{C}$ for $7 \mathrm{hr}$ in an incubator/shaker set at $150 \mathrm{rpm}$. Preliminary studies (data not shown) confirmed that this procedure yielded an E. coli culture at stationary phase of growth.

As described before (see Sample preparation), the 7-hr E. coli culture was used as the inoculum for the next sample of ground beef and cycle of e-beam processing. The isolation of E. coli survivors following e-beam processing was repeated four times and a total of five cycles of e-beam processing were conducted. In the first cycle of e-beam processing, the ATCC E. coli strain 35150 was used. The E. coli survivors isolated following the first cycle of e-beam processing were designated as L1 (hereafter called isolate L1), while the E. coli survivors isolated following the second cycle of e-beam processing using isolate L1 was designated as L2 (hereafter called isolate L2). Isolates L3 and L4 were obtained accordingly.

\section{Determining $D_{10}$-values}

E. coli survivors following each cycle of e-beam processing were plotted on a logarithmic scale as a function of e-beam dose $(\mathrm{kGy})$, resulting in survivor curves. The $\mathrm{D}_{10^{-}}$ value was determined by calculating the negative reciprocal of the slope of the survivor curve (equation 1) (Jaczynski and Park, 2003). $\mathrm{D}_{10}$-value is recognized as the radiation dose needed to achieve one log cycle or $90 \%$ reduction of the microbial population (Urbain, 1986).

$$
\log \left(\frac{N}{N_{0}}\right)=-\frac{1}{D_{10}} * t \quad \text { Equation } 1
$$

$\mathrm{N}$ - number of survivors at e-beam dose, $\mathrm{N}_{0}$ - initial microbial concentration, 
$\mathrm{D}_{10}-\mathrm{D}_{10}$-value, decimal reduction dose,

$\mathrm{t}$ - e-beam dose.

\section{Statistics}

Five cycles of e-beam processing were conducted, three separate experiments $(\mathrm{n}=3)$ per one cycle. Meat samples were randomly assigned to e-beam doses in each experiment. All bacterial enumerations were performed in duplicate and the mean values are reported as $\mathrm{CFU} / \mathrm{g}$. The enumeration counts (CFU/g) were log-converted and analyzed by linear regression using MS Office Excel software (Version 2003) in order to determine $\mathrm{D}_{10}$-values. Analysis of variance (ANOVA) was performed for a completely random sample model to detect significant differences in microbial survival with increasing e-beam dose. Dunnett's method of means comparison was used to compare the mean $\mathrm{D}_{10}$-values for each cycle of ebeam processing. All statistical analyses were calculated using JMP software (SAS Institute, 2002).

\section{RESULTS AND DISCUSSION}

Survivor curves were plotted for E. coli O157:H7 ATCC 35150 (Fig. 2) and each successive isolate (L1, L2, L3, and L4) following repetitive e-beam processing (Fig. 3, 4, 5, and 6). The linear regression analysis of survivor curves yielded high correlation coefficients $\left(\mathrm{R}^{2}\right)$. The $\mathrm{D}_{10}$-values for each isolate, therefore, were calculated from the survivor curves as a function of e-beam dose (Table 1).

The ATCC strain had not previously been subjected to e-beam radiation before this experiment and the respective $\mathrm{D}_{10}$-value was expectedly the lowest at $0.24 \mathrm{kGy}$ (Fig. 2). The highest $(\mathrm{P}<0.05) \mathrm{D}_{10}$-value $(0.63 \mathrm{kGy})$ was determined for isolate $\mathrm{L} 3$ following the third cycle 
of e-beam processing (Fig. 5). However, no further significant increases $(\mathrm{P}>0.05)$ were seen for the fourth and final cycle of e-beam processing, with isolate L4 resulting in a $\mathrm{D}_{10}$-value of $0.60 \mathrm{kGy}$ (Fig. 1). This was probably due to the fact that not all of the surviving E. coli cells had identical radio-resistance. Likely, the surviving cells showed some distribution of radioresistance. The distribution of microbial resistance due to application of various preservation processes has been described by Peleg and Cole (1996). Therefore, the isolated survivors that were used for subsequent cycles of e-beam processing in our experiments could have had various levels of radio-resistance to e-beam. In order to minimize this effect, the colonies following enumeration of survivors were isolated in a random manner and grown for inoculation of ground beef for subsequent cycles of e-beam processing. However, even with random isolation, variation in the radio-resistance of $E$. coli isolates was reflected in our data as for example between isolates L3 and L4 (Fig. 1).

Analysis of variance (ANOVA) showed that the more microorganisms were subjected to e-beam processing, the greater their radio-resistance to e-beam $(\mathrm{P}<0.05)$ (Table 1). In addition, Dunnett's method of means comparison showed that while the first two cycles of ebeam processing yielded $\mathrm{D}_{10}$-values insignificantly $(\mathrm{P}>0.05)$ different from the $\mathrm{D}_{10}$-value for the ATCC strain, the third and fourth cycles of e-beam processing resulted in significant increases $(\mathrm{P}<0.05)$ of $\mathrm{D}_{10}$-value for isolates $\mathrm{L} 3$ and $\mathrm{L} 4$, respectively when compared to the $\mathrm{D}_{10}$-values for the ATCC strain, L1, and L2 (Fig. 1).

Previous work by Black and Jaczynski (2006, 2007a, 2007b) demonstrated that sublethal growth conditions for E. coli $\mathrm{O} 157: \mathrm{H} 7$ such as freezing temperatures, reduced water activity $\left(A_{w}\right)$, and elevated ionic strength (IS) increase the $D_{10}$-values for E. coli O157:H7 in various food matrices subjected to e-beam. In the current research, we ensured that these factors did not affect the $\mathrm{D}_{10}$-value and therefore, did not confound increased radio-resistance 
due to repetitive e-beam processing at sub-lethal doses. Rodriguez et al. (2006) investigated surrogate microorganisms for common food-borne pathogens including E. coli in a model food system $(10 \% \mathrm{w} / \mathrm{w}$ gelatin) for determination of inactivation kinetics with e-beam. Rodriguez et al. (2006) concluded that non-pathogenic E. coli K-12 was more radio-resistant than E. coli $\mathrm{O} 157: \mathrm{H} 7$ and determined $\mathrm{D}_{10^{-}}$-values at 0.88 and $0.36 \mathrm{kGy}$, respectively. The $\mathrm{D}_{10^{-}}$ value reported by these investigators for E. coli $\mathrm{O} 157: \mathrm{H} 7$ is similar to ours and a small difference is likely due to different food sample and much higher e-beam energy used in our experiment.

Buchanan et al. (1999) demonstrated that E. coli O157:H7 incubated under acidic conditions were more likely to survive exposure to subsequent acidic environment, which was attributed to the induction of a $\mathrm{pH}$-dependent stationary phase of microbial growth. Likely, the prior exposure to acid stimulated an increased acid resistance in the microorganisms. E. coli $\mathrm{O} 157: \mathrm{H} 7$ that were able to survive repetitive e-beam processing may have undergone a similar mechanism for increased radio-resistance. However, Buchanan et al. (1999) allowed for the recovery of injured cells, which were in the range of 65 to $99 \%$ of total viable cells, by plating on a nutrient medium (brain heart infusion agar). The selective media used in our experiments to enumerate survivors did not allow for the recovery of e-beam injured bacteria; therefore, the cells that survived and grew following e-beam processing were either un-injured by radiation or had developed an advanced method of DNA repair in order to repair the damage induced by the radiation. If we had enumerated e-beam survivors using a nutrient medium allowing injury recovery, the resultant $\mathrm{D}_{10}$-values would most likely have been even greater. Buchanan et al. (2004) theorized that acid habituation may synergistically increase microbial resistance to ionizing radiation, resulting in a cross-protection. They determined that acid resistant E. coli strains had approximately a two-fold greater $\mathrm{D}_{10}$-value than the non-acid 
resistant strains when inactivated with ionizing radiation. Therefore, similar to our research, this data suggests that $E$. coli is capable of developing an increased radio-resistance.

Leyer et al. (1995) proposed that acid resistance is due to E. colis ability to develop an acid tolerant response induced in stationary phase cells incubated at sub-lethally low $\mathrm{pH}$. In this regard, a similar mechanism can be proposed for the increased radio-resistance of E. coli to e-beam determined in our experiment. When the E. coli survivors following e-beam processing were isolated and repetitively re-processed with e-beam at sub-lethally high doses, it is possible that they were able to develop a more e-beam tolerant response, resulting in greater radio-resistance to e-beam as evidenced by higher $\mathrm{D}_{10}$-values (Fig. 2, 3, 4, 5, and 6).

Arnold and Kaspar (1995) demonstrated a genetic mechanism involved in the development of the tolerant response to various stressors, which was attributed to the rpoS gene. Their research showed that if the rpoS gene is intact, E. coli can develop greater resistance to various stressors. In a subsequent study, Cheville et al. (1996) used rpoS mutant and non-mutant E. coli strains and determined that mutant strains were less resistant to heat, acid, and high ionic strength than the non-mutant strains, confirming that the intact $r p o S$ gene is necessary for increased resistance to those stressors. Cheville et al. (1996) theorized that this gene likely encodes proteins or increases the transcription of proteins that are pivotal in microbial resistance. Lin et al. (1996) also confirmed that the rpoS gene is involved in the development of increased acid resistance in enterohemorrhagic E. coli. The development of the increased heat resistance of E. coli has also been linked to the rpoS gene and another heat shock gene, the rpoH gene (Yuk et al. 2003). The genetic mechanism involving the rpoS gene may also play an important role in the development of the increased radio-resistance of E. coli to ebeam. In this study, E. coli were grown in TSB and ground beef, which are nutrient and water rich growth media. Most likely, the rpoS gene was intact prior to e-beam processing. The 
microorganisms were subjected to e-beam while in the stationary phase of their growth, and therefore, the intact rpoS gene likely contributed to the development of the increased radioresistance to e-beam as evidenced by greater $\mathrm{D}_{10}$-values. Current studies are investigating the genetic mechanism involved in the development of increased microbial radio-resistance to ebeam with micro-arrays. Micro-array is an emerging technique with the capability of highthroughput, allowing rapid gene expression and comparative surveys of large numbers of microbial specimens. Preliminary micro-array data suggests a correlation between up- and down-regulation of some genes and increased radio-resistance of E. coli to e-beam.

The direct mechanism of microbial inactivation due to ionizing radiation, including ebeam is the damage of microbial DNA (Urbain, 1986). Since injured cells were not recovered in our experiments, the DNA had to be fully intact and functional in the survivor cells that reproduced and formed colonies during our enumeration procedure. Therefore, E. coli likely has a mechanism for DNA repair after significant damage caused by e-beam. The development of increased capability to repair DNA may also explain in part an increased radio-resistance of E. coli subjected to repetitive e-beam processing as determined in our experiments. Inactivation of E. coli caused by the DNA damage was shown by Imlay and Linn (1987) who subjected E. coli to sub-lethal concentrations of hydrogen peroxide. The surviving microorganisms developed an increased resistance via a greater repair of recombinational DNA. Their research also suggested that the repair of recombinational DNA is non-specific and may be a general mechanism for microbial response to various stressors. Witkin (1976) showed that UV radiation induces several mechanisms of DNA repair in E. coli, suggesting the use of a number of different genes. While UV radiation and hydrogen peroxide do not cause the same damage to DNA as e-beam, the data from literature illustrating E. colis capability for the DNA repair following exposure to UV and other stressors indicates that a similar 
mechanism may contribute to the development of increased radio-resistance of this microorganism to e-beam as determined in our experiments.

Several theories have been proposed as possible mechanisms for the development of increased resistance of E. coli to various stressors. However, it is likely that it is a combination of several of these mechanisms that confer increased radio-resistance of E. coli to e-beam. More research is needed in this area to fully understand the mechanism of increased microbial resistance to e-beam. The increased microbial resistance of food-borne pathogens such as E. coli $\mathrm{O} 157: \mathrm{H} 7$ has significant practical implications for the food industry and general public health. Most likely, the use of genetic analysis (through micro-arrays, for example) will offer food processors and regulatory agencies a method for rapid detection of pathogenic strains with increased radio-resistance; and if they occur, a proper counteraction can be devised.

\section{CONCLUSIONS}

E. coli $\mathrm{O} 157: \mathrm{H} 7$ has been shown to develop an increased resistance to a variety of stressors such as low $\mathrm{pH}$, increased temperature and ionic strength, and antibiotics. The $\mathrm{D}_{10^{-}}$ values for E. coli $\mathrm{O} 157: \mathrm{H} 7$ inoculated in ground beef and repetitively subjected to e-beam resulted in a significant increase $(\mathrm{P}<0.05)$ from $0.24 \pm 0.03$ to $0.63 \pm 0.02 \mathrm{kGy}$ for ATCC strain 35150 and isolate L3, respectively. Following four cycles of e-beam processing, the microorganisms were able to resist doses as high as $3.0 \mathrm{kGy}$. While e-beam can efficiently inactivate E. coli in food products, it also has the capability to develop increased resistance to ebeam if the same populations of E. coli in food products were to be repetitively subjected to ebeam processing. Many mechanisms have been proposed for the development of increased resistance of E. coli to various stressors in food products. An exact mechanism for the increased radio-resistance of this food-borne pathogen to e-beam is still unclear and due to its 
practical relevance for the food industry and general public health, the mechanism should be identified by further research.

\section{ACKNOWLEDGEMENTS}

This research was funded by the USDA Hatch program (project nr WVA00429). Special thanks to Sterigenics International for allowing us to use their e-beam facility. Our appreciation extends to Carl A. Zinn and Richard Vallejo of Sterigenics for invaluable technical

expertise with e-beam, Sarah K. Beamer for technical assistance in the laboratory, and Ida Holaskova for assistance with statistical analysis. 


\section{REFERENCES}

Arnold, K.W., Kaspar, C.W., 1995. Starvation- and stationary-phase-induced acid tolerance in Escherichia coli O157:H7. Applied and Environmental Microbiology 61, 2037-2039.

Bell, C., Kyriakides, A., 1999. E. coli, a practical approach to the organism and its control in foods. Blackwell Science, London, pp 200.

Benjamin, M.M., Datta, A.R., 1995. Acid tolerance of enterohemorrhagic Escherichia coli. Applied and Environmental Microbiology 61, 1669-1672.

Black, J.L., Jaczynski, J., 2006. Temperature effect on inactivation kinetics of Escherichia coli O157:H7 by electron beam in ground beef, chicken breast meat, and trout fillets. Journal of Food Science 71, 221-227.

Black, J.L., Jaczynski, J., 2007a. Effect of ionic strength on inactivation kinetics of Escherichia coli $\mathrm{O} 157: \mathrm{H} 7$ by electron beam in ground beef, chicken breast meat, and trout fillets. International Journal of Food Science and Techonology. In Press doi:10.1111/j.13652621.2006.01310.

Black, J.L., Jaczynski, J., 2007b. Effect of water activity on inactivation kinetics of Escherichia coli $\mathrm{O} 157: \mathrm{H} 7$ by electron beam in ground beef, chicken breast meat, and trout fillets. International Journal of Food Science and Techonology. In Press doi:10.1111/j.13652621.2006.01480.

Buchanan, R.L., Edelson, S.G., Boyd, G., 1999. Effects of pH and acid resistance on the radiation resistance of enterohemorrhagic Escherichia coli. Journal of Food Protection 62, 219-228.

Buchanan, R.L., Edelson-Mammel, S.G., Boyd, G., Marmer, B.S., 2004. Influence of acidulant identity on the effects of $\mathrm{pH}$ and acid resistance on the radiation resistance of Escherichia coli O157:H7. Food Microbiology 21, 51-57. 
Centers for Disease Control and Prevention, 1997. Outbreaks of Escherichia coli O157:H7 infection and cryptosporidiosis associated with drinking unpasteurized apple cider Connecticut and New York, October 1996. MMWR Morbidity and Mortality Weekly Report 1997 46(01), 4-8.

Cheville, A.M., Arnold, K.W., Buchrieser, C., Cheng, C.M., Kaspar, C.W., 1996. rpoS regulation of acid, heat, and salt tolerance in Escherichia coli O157:H7. Applied and Environmental Microbiology 62, 1822-1824.

Imlay, J.A., Linn, S., 1987. Mutagenesis and stress responses induced in Escherichia coli by hydrogen peroxide. Journal of Bacteriology 169, 2967-2976.

The International Commission on Microbiological Specifications for Foods. 1996. Intestinally pathogenic Escherichia coli. In Micro-organisms in Foods 5 Microbiological Specifications of Food Pathogens. Blackie Academic and Professional, London, pp 126-140.

Jaczynski J., Park J.W., 2003. Microbial inactivation and electron penetration in surimi seafood during electron beam processing. Journal of Food Science 68, 1788-1792.

James, D.L., Jaczynski, J., Matak, K.E., 2007. Effect of electron beam irradiation on acidresistant Salmonella Montevideo in tomatoes. Journal of Food Protection. Submitted.

Jay, J.M., Loessner, M.J., Golden, D.A., 2005. Foodborne gastroenteritis caused by Escherichia coli. In: J.M. Jay, M.J. Loessner, D.A. Golden (Eds.), Modern Food Microbiology, $7^{\text {th }}$ ed. Springer Science, New York, pp. 637-655.

Leyer, G.J., Wang, L., Johnson, E.A., 1995. Acid adaptation of Escherichia coli O157:H7 increases survival in acidic foods. Applied and Environmental Microbiology 61, 37523755. 
Lin, J., Smith, M.P., Chapin, K.C., Baik, H.S., Bennett, G.N., Foster, J.W., 1996. Mechanisms of acid resistance in enterohemorrhagic Escherichia coli. Applied and Environmental Microbiology 62, 3094-3100.

Peleg, M., Cole, M.B., 1996. Reinterpretation of microbial survival curves. Critical Reviews in Food Science and Nutrition 38, 353-380.

Rodriguez, O., Castell-Perez, M.E., Ekpanyaskun, N., Moreira, R.G., Castillo, A., 2006. Surrogates for validation of electron beam irradiation of foods. International Journal of Food Microbiology 110, 117-122.

SAS Institute. 2002. SAS/STAT guide for personal computers, version 8.1. SAS Institute, Cary (NC).

Schroeder, C.M., Zhao, C., DebRoy, C., Torcolini, J., Zhao, S., White, D.G., Wagner, D.D., McDermott, P.F., Walker, R.D., Meng, J., 2002. Antimicrobial resistance of Escherichia coli $\mathrm{O} 157$ isolated from humans, cattle, swine, and food. Applied and Environmental Microbiology 68, 576-581.

Tauxe, R.T., 2001. Food safety and irradiation: protecting the public from foodborne infections. Emerging Infectious Diseases 7(3 Suppl), 516-521.

Urbain, W.M., 1986. Food Irradiation. Academic Press, Orlando, pp 351.

U.S. Department of Agriculture, 1999. Irradiation of meat food products. Federal Register 64(246), docket no. 97-076F.

U.S. Food and Drug Administration. Spinach and E. coli outbreak. Accessed on September 21, 2006. http://www.fda.gov/oc/opacom/hottopics/spinach.html. 
Yuk, H., Marshall, D.L., 2003. Heat adaptation alters Escherichia coli O157:H7 membrane lipid composition and verotoxin production. Applied and Environmental Microbiology 69, 5115-5119.

Yuk, H., Marshall, D.L., 2004. Adaptation of Escherichia coli O157:H7 to pH alters membrane lipid composition, verotoxin secretion, and resistance to simulated gastric fluid acid. Applied and Environmental Microbiology 70, 3500-3555.

Witkin, E.M., 1976. Ultraviolet mutagenesis and inducible DNA repair in Escherichia coli. Bacteriological Reviews 40, 869-907.

World Health Organization. Accessed on April 25, 2007. http://www.who.int/mediacentre/factsheets/fs125/en/ 


\section{FIGURE CAPTIONS}

Figure $1 . \mathrm{D}_{10}$-values for E. coli $\mathrm{O} 157: \mathrm{H} 7$ in ground beef subjected repetitively to sub-lethal levels of e-beam radiation. Small bars on the data bars indicate standard deviation. Different letters on the top of data bars indicate significant differences between mean $\mathrm{D}_{10}$-values of the E. coli $\mathrm{O} 157: \mathrm{H} 7$ isolates $(\mathrm{P}<0.05)$.

Figure 2. Survivor curve for E. coli O157:H7 (ATCC 35150) in ground beef subjected to ebeam. Bars on the data points indicate standard error.

Figure 3. Survivor curve for E. coli isolate L1 (E. coli ATCC 35150 that was subjected to ebeam and survived) in ground beef subjected to e-beam. Bars on the data points indicate standard error.

Figure 4. Survivor curve for E. coli isolate L2 (E. coli isolate L1 that was subjected to e-beam and survived) in ground beef subjected to e-beam. Bars on the data points indicate standard error.

Figure 5. Survivor curve for E. coli isolate L3 (E. coli isolate L2 that was subjected to e-beam and survived) in ground beef subjected to e-beam. Bars on the data points indicate standard error.

Figure 6. Survivor curve for E. coli isolate L4 (E. coli isolate L3 that was subjected to e-beam and survived) in ground beef subjected to e-beam. Bars on the data points indicate standard error. 
Figure 1

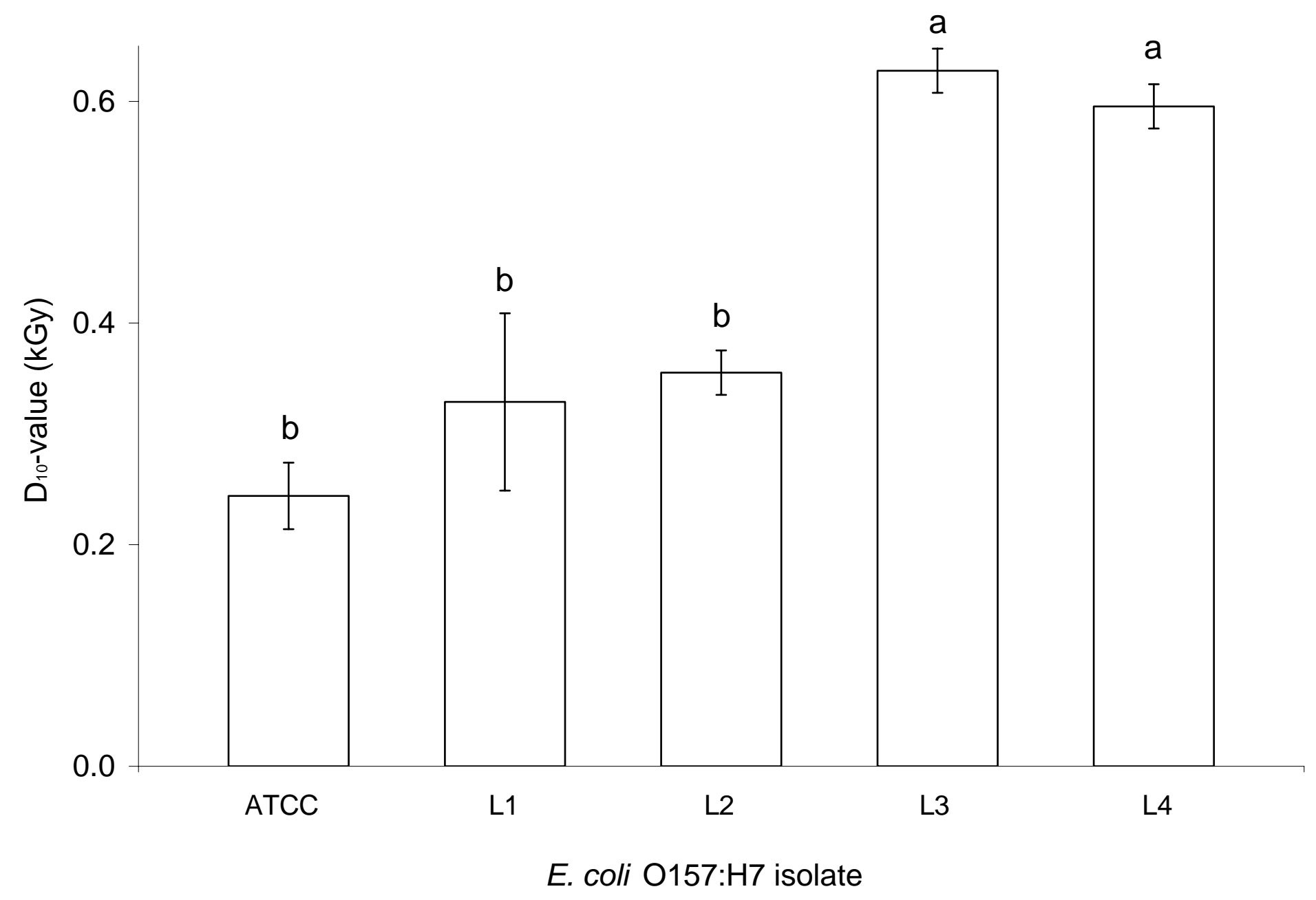


Figure 2

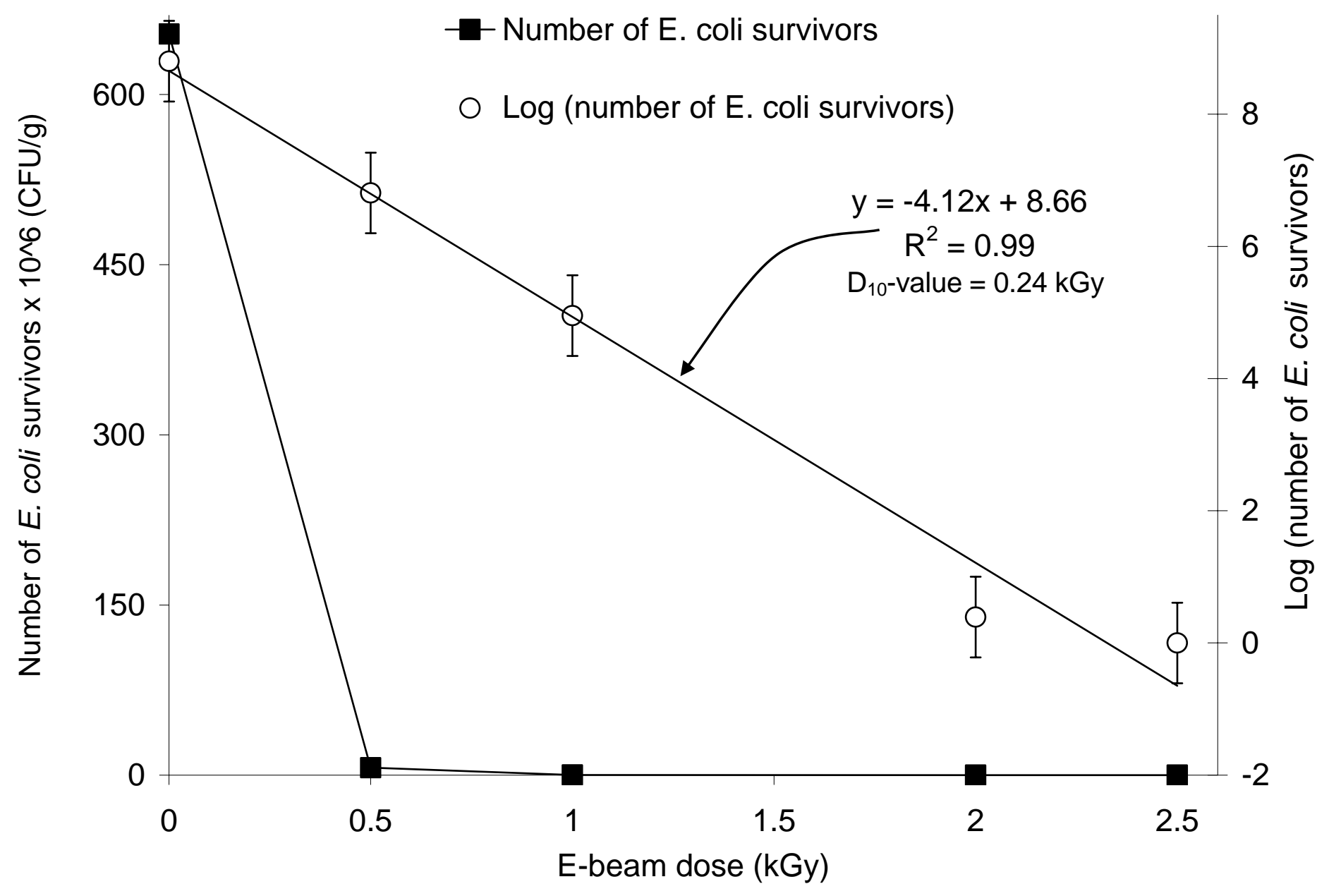


Figure 3

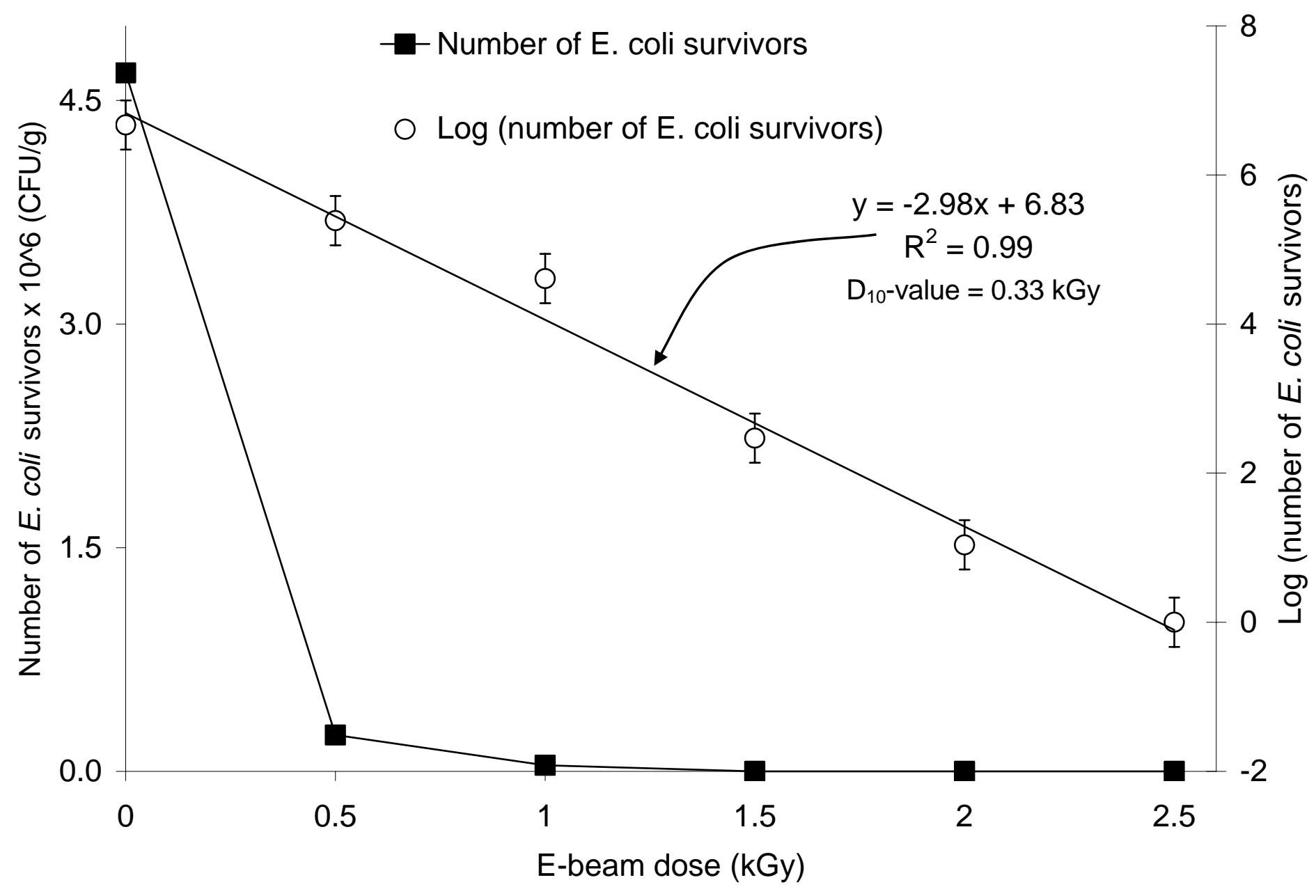


Figure 4

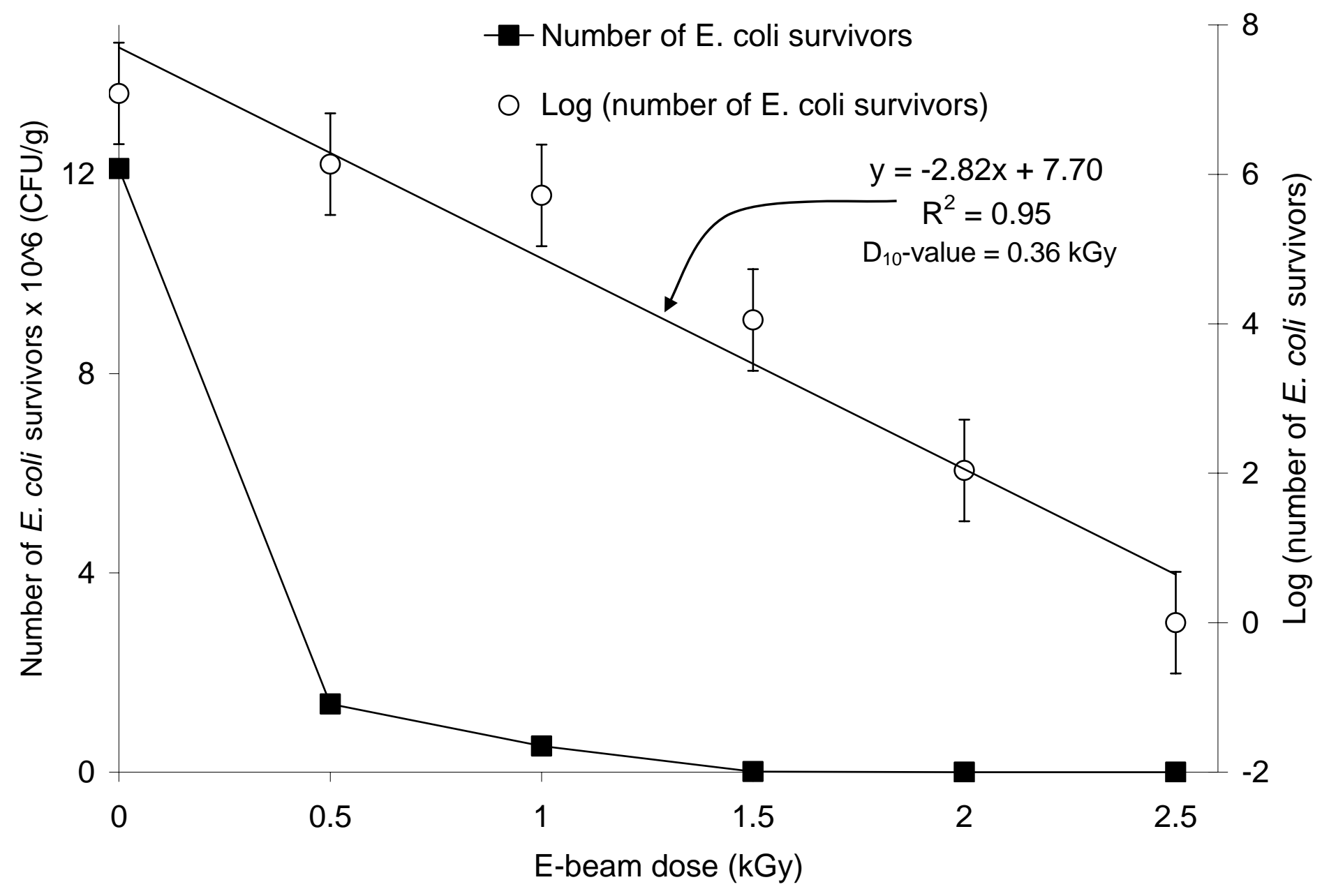


Figure 5

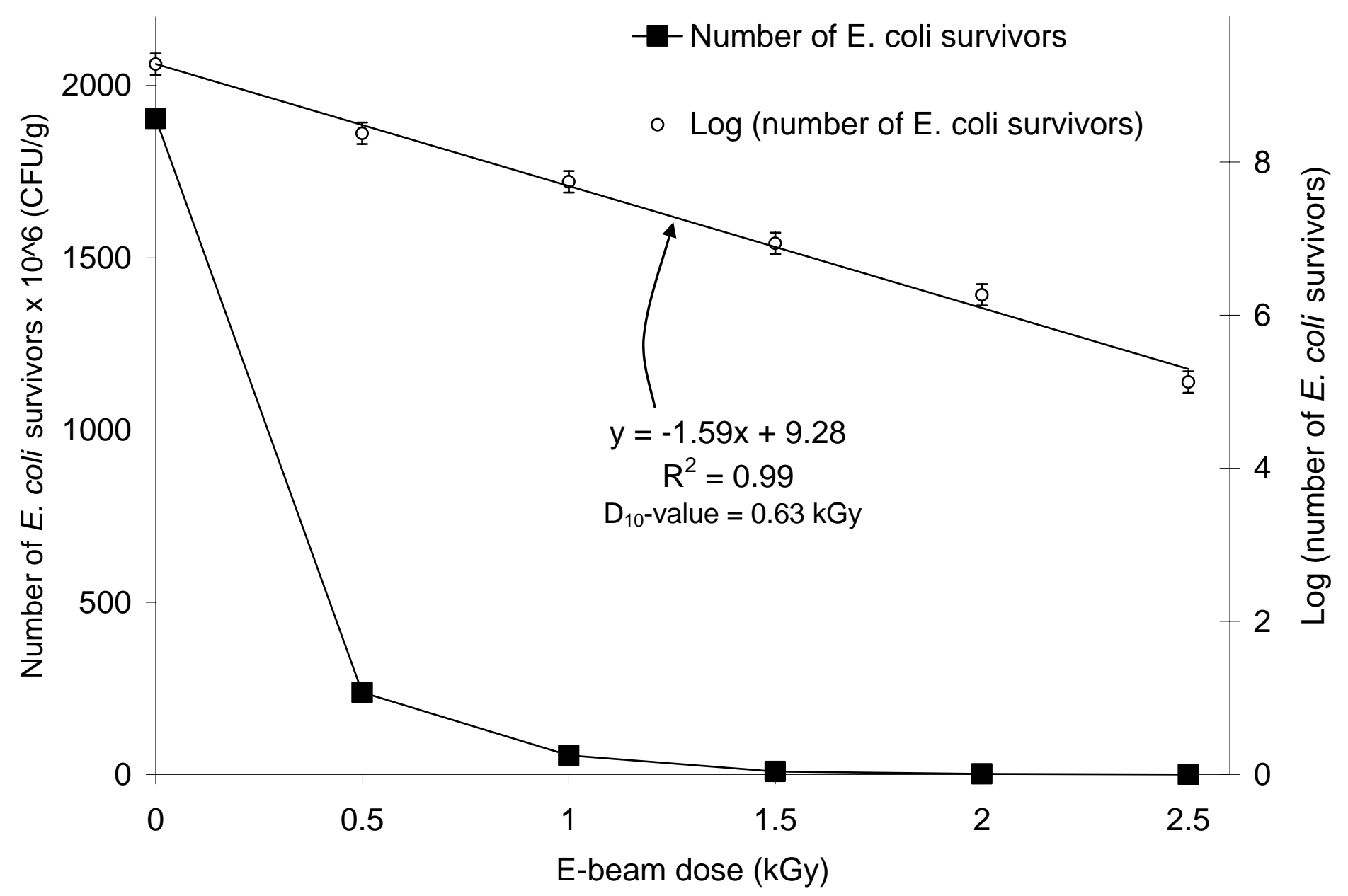


Figure 6

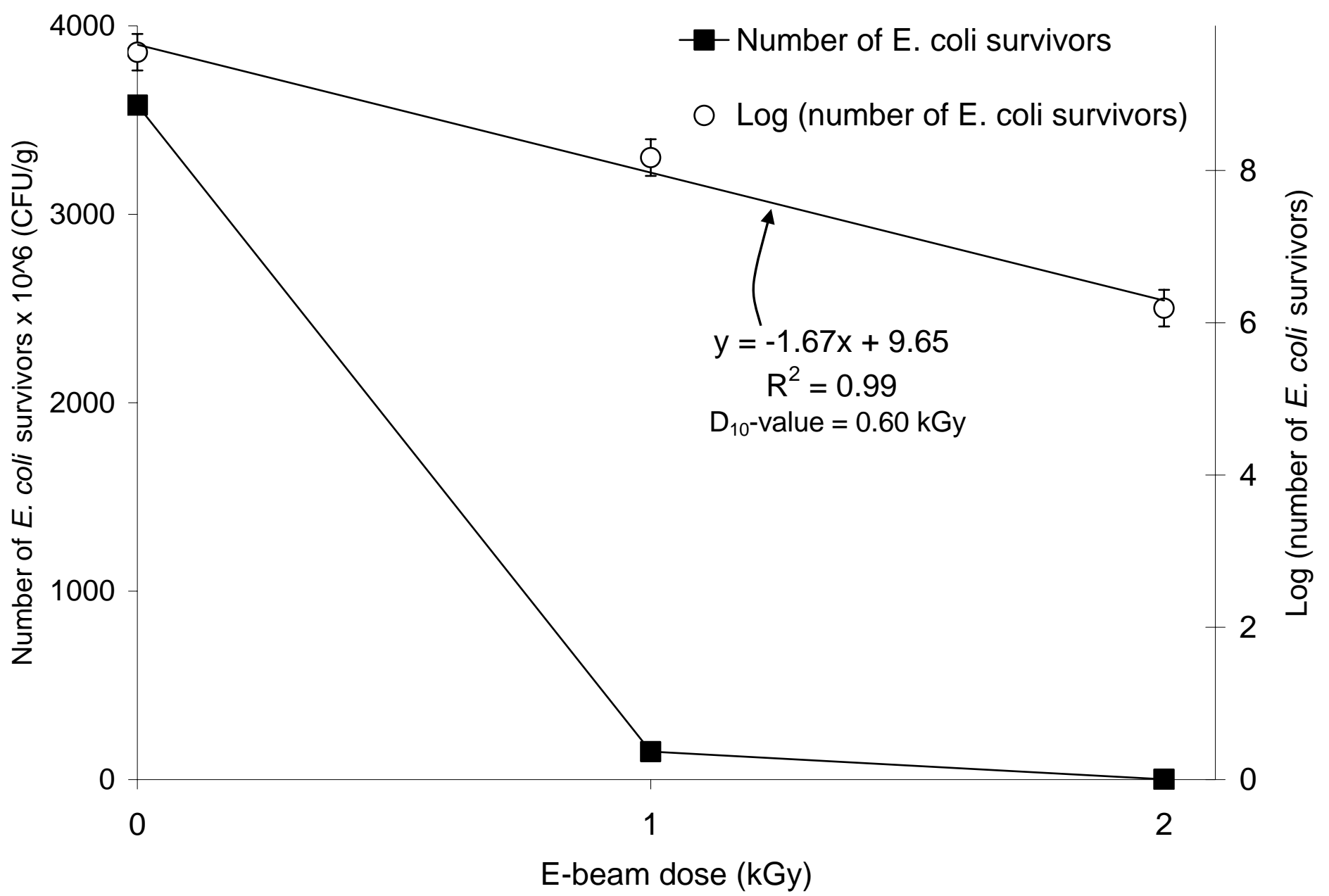


Table 1

Increased radio-resistance of $E$. coli O157:H7 in ground beef subjected repetitively to sublethal levels of e-beam irradiation. Data are given as mean \pm standard deviation $(n=3)$. Mean $\mathrm{D}_{10}$-values in horizontal row with different letters indicate significant differences ( $\mathrm{P}$ $<0.05)$.

\section{E. coli O157:H7 isolate}

\begin{tabular}{c|c|c|c|c|c|}
\multicolumn{2}{c}{ ATCC 35150} & L1 & L2 & L3 & L4 \\
\hline $\mathbf{D}_{10}$-value & $0.24 \pm 0.03 \mathrm{~b}$ & $0.33 \pm 0.08 \mathrm{~b}$ & $0.36 \pm 0.02 \mathrm{~b}$ & $0.63 \pm 0.02 \mathrm{a}$ & $0.60 \pm 0.02 \mathrm{a}$ \\
$\mathbf{R}^{2}$ & 0.99 & 0.99 & 0.95 & 0.99 & 0.99 \\
\hline
\end{tabular}




\section{An Analysis of Genes of Escherichia coli Resistance}

\section{INTRODUCTION}

Food-borne illnesses caused by enterohemmorhagic bacteria such as Escherichia coli cause millions of illnesses which cause hundreds of deaths (Altekruse, et al. 1997). While E. coli is a natural inhabitant of the digestive tracts of humans and animals, certain strains of E. coli such as $\mathrm{O} 157: \mathrm{H} 7$ have recently emerged as pathogens that can be extremely harmful to humans when ingested in large quantities (Bell and Kyriakides, 1998; Tauxe 2002). This can cause such painful symptoms as cramping, vomiting, and diarrhea and could potentially lead to the more serious renal disorder hemolytic uremic syndrome, which can result in death (WHO, 2007). E. coli O157:H7 is most typically found in meats such as ground beef, which is more prone to contamination due to the grinding process; however, recent outbreaks of E. colirelated illnesses in foods such as apple cider and lettuce have caused some concern about effective means of microbial inactivation. Foods such as apple cider had previously been considered safe from contamination by E. coli and other illness-causing bacteria due to their low $\mathrm{pH}$ of approximately 4.5. It is now widely acknowledged that many bacteria, especially $E$. coli $\mathrm{O} 157: \mathrm{H} 7$, have the ability to adapt both physically and metabolically to endure such harsh environmental conditions as low $\mathrm{pH}$, high temperature, high salinity, and antibiotics.

One antimicrobial method that has emerged as a way to circumvent the problem of resistance without altering food quality is the use of radiation, specifically electron beam radiation (e-beam). E-beam is a nonthermal inactivation method similar to pasteurization that disrupts DNA by introducing cross-links, rendering the organism unable to reproduce its DNA (EPA - Food Irradiation 2007). The more complex an organism, the more susceptible its DNA is to e-beam; therefore, an organism as small as E. coli can withstand a higher dose 
than a more evolved organism (Tauxe 2001). The maximum dose of e-beam radiation allowed for refrigerated meats is 4.5 kilograys $(\mathrm{kGy})$, while the maximum dose for frozen foods is 7.0 kGy. However, it has recently been established that E. coli O157:H7 also has the ability to survive and adapt to electron beam irradiation at levels approaching the recommended maximum dosage of $4.5 \mathrm{kGys}$ (Levanduski \& Jaczynski, 2007). In light of this new research, it is necessary to devise a rapid screening method for the detection of radio-resistant strains of bacteria in order to avoid exposing these strains to additional radiation, unwittingly increasing their resistance even further. In addition, according to Dowd and Ishizaki (2006), using microarray as a rapid detection method for radio-resistant strains that will be more difficult to eliminate through radiation or that could possibly harbor more virulent factors would significantly reduce the number of Class I recalls of beef products by eliminating the marketing of foods carrying resistant strains to consumers.

One method that has been suggested for this rapid detection is through the use of oligonucleotide microarray analysis. This technique utilizes probes generated from all possible genes contained within an organism to hybridize with a sample of fluorescently labeled complementary DNA (cDNA) prepared from the messenger RNA (mRNA) of the two strains of interest by reverse transcriptase. Because bacterial mRNA does not have a polyA tail, oligodT could not be used as is normally done for vertebral tissue gene analysis. Instead, cDNA was prepared from mRNA by way of random hexamers, which indiscriminately and randomly adhere to the mRNA and then elongate to form cDNA. The amount of fluorescence from each of the sample strains is then scanned and quantitated to determine how gene expression has been altered by the procedure in question; in this case, repeated exposure to sub-lethal doses of electron beam irradiation. The higher the fluorescence, the more the gene is expressed and vice versa. 
We were able to formulate several hypotheses as to which genes should be most affected by repeated exposure to e-beam radiation at sub-lethal doses based on previous work on genetic analyses of other resistant strains. No study has been done as of yet that has attempted a genome-wide analysis by micro-array of the effects of resistance to e-beam radiation on E. coli $\mathrm{O} 157: \mathrm{H} 7$.

One of the most important methods of radio-resistance in light of the fact that injured cells were not recovered in the previous experiment is that of increased DNA repair. Therefore, we must first establish several methods by which E. coli is able to promptly repair its DNA after it has been damaged. The first of these is the SOS response, which protects DNA in the major groove from damage via methylation (Little and Mount 1982). The response must first be induced by a signal that simply represents some change in the normal milieu of the cell (in this case, damage to the cell's DNA), which activates a series of reactions. The induction signal activates the RecA protein protease to cleave and inactivate the LexA repressor protein. The SOS genes are then translated at a vastly increased rate until the damage is repaired, at which point, their expression level drops. More than 30 genes are thought to be repressed by the LexA protein and activated upon its cleavage (Khil and Camerini-Otero 2002), including the din genes (damage-inducible genes which have unknown function), the excision repair gene wrrA, and many others (Little and Mount 1982). It is unlikely, however, that an increase in the genes of the SOS response will show a drastic increase in regulation on a microarray study, however, because the expression levels of both RecA and LexA drop within hours of application of the DNA-damaging agent (Little and Mount 1982).

Khil and Camerini-Otero (2002) found that upon treatment of E. coli with mitomycin C (a DNA-specific chemotherapy drug that induces interstrand cross-links), nearly 30\% of all 
genes present showed significant differences in their respective expression levels. They reasoned that since DNA is an absolutely essential aspect of life, any treatment resulting in its damage, compounded with the fact that E. coli has such a short generation time and thus a rapid growth rate, will affect many more genes when compared with other forms of inactivation. Of those genes affected, roughly $22 \%$ showed an up-regulation of expression levels, including many SOS-inducible genes as well as others involved in transport, membrane structure, nucleotide biosynthesis, degradation, detoxification, and regulation of gene expression. A much higher number of genes were found to be down-regulated after exposure to mitomycin $\mathrm{C}$, including some ribosomal genes, those involved in protein synthesis, and some subunits of DNA polymerase III (although not polymerases I or II). This is not a surprising result since DNA polymerase III is the primary polymerase involved in replication of DNA, while polymerases I and II function more in proofreading and correcting errors (Khil and Camerini-Otero 2006).

UV radiation is a comparable treatment to electron beam because it inactivates microbes in much the same way, by inducing DNA damage by introducing thymine-thymine dimers in the DNA, rendering the replication machinery unable to replicate and reproduce the DNA. Most cells repair the damage done by UV radiation by the process of nucleotide excision repair, which simply removes the thymine-thymine dimers. A study done by Courcelle et al. (2001) examined the genetic consequences of UV exposure on both wild type and SOS-deficient E. coli cells. Many of the genes that exhibited an increase in expression levels were directly regulated by the SOS response gene lex $A$. Expectedly, most of the upregulated genes that are linked to lexA are for proteins involved in DNA repair (i.e. $\operatorname{rec} N)$, excision nucleases (i.e $u v r B$ ), inhibitors of cell division (i.e. $s u l A$ ), and heat shock proteins (i.e. $i b p B$ and $h s l U)$. The majority of the up-regulated genes showed the highest expression levels at 
40 minutes after exposure to radiation and then expression gradually decreased after this point. It is also important to note that some of the genes that were up-regulated are not associated with the LexA-controlled SOS response. Among the most significant of these are the ribonucleotide reductase genes $n r d A$ and $n r d B$, which function to control the synthesis of DNA by regulating the cellular concentration of the diphosphate precursors of deoxyribonucleotides. Also among the induced genes of LexA-independent origin are additional heat shock proteins, chaperones, and genes involved with purine, pyrimidine, and RNA metabolism. The increased expression of these genes was only seen for the wild type cells with an intact SOS response. SOS-deficient cells showed no increased activity in any of the aforementioned genes. In addition, some genes must also be repressed after a trauma such as UV exposure. The researchers hypothesized that the down-regulation was due to an active repression process within the cell or a direct result of the damage caused by UV radiation (Courcelle et al. 2001).

Heat shock proteins are vital to any organism and serve as chaperones for the correct refolding of proteins after denaturation due to some stress. Denaturation of proteins is most commonly caused by heat; however, other sources (such as radiation) which cause DNA damage may cause the sequence to be misread, leading to misfolded proteins and thus may initiate the transcription of heat shock genes, which is evidenced by research of Thomas and Baneyx (1998). The adjacent $i b p A$ and $i b p B$ genes were manipulated in this study by the replacement of a kanamycin resistance gene in order to achieve a null mutation of the heat shock genes. Thomas and Baneyx (1998) showed that the lack of these specific heat shock proteins was not detrimental when a mild heat stress was applied; however, when an extreme heat stress was utilized, the loss of these genes caused decreased viability at temperatures above $46^{\circ} \mathrm{C}$. Additionally, when these heat shock proteins were over-expressed, a 5- to 10- 
fold decrease in viability at $50^{\circ} \mathrm{C}$ was observed. The observation that these proteins are not necessarily needed for the correct refolding of proteins after the application of a denaturing stress led Thomas and Baneyx to the conclusion that the heat shock proteins are not the only proteins that play a main chaperone role in refolding, but instead are part of vast array of reconstructive genes which work in concert as a back-up system in case one of them should fail (1998). Following this reasoning, it may be that many of the unknown genes that are observed to be up-regulated as a result of a DNA-damaging stress may in fact be involved in the refolding of damaged proteins.

It has been suggested that tolerance to certain environmental stresses may not be because of any particular adaptive qualities incurred by the cell, but rather is a result of the cell's ability to enter into a protective stationary phase and not necessarily a result of (or perhaps in combination with) a system of DNA repair (Cheville et al. 1996). Entrance into this phase is under the control of the rpoS gene system, which regulates some 30 genes. Cheville et al. (1996) have demonstrated that a strain of E. coli lacking the rpoS gene system was significantly less tolerant to acid, heat, and salt challenges than a strain with an intact rpoS system. They reasoned that this system of genes is up-regulated when the cell is placed in an environment that is not conducive for growth and survival and produces proteins that are either lacking or exhibit very low expression in optimal growth conditions (Cheville et al. 1996). Interestingly, this gene was found to be unchanged after a treatment of UV exposure (Courcelle et al. 2001), which is perhaps due to the fact that it plays no role in the repair of DNA damage.

One gene in particular has been found to play a role in both protection against oxidative stress and high pressure resistance is the Dps gene. The example of protection against oxidative stress is of particular interest to us due to the fact that e-beam causes the 
formation of oxygen radicals, which contribute to microbial death via the indirect effect of water radiolysis (Black and Jaczynski, 2006). When the bacterial cell experiences oxidative stress, repair mechanisms are initiated to scavenge the oxidative culprit and restore the nucleic acids to their functional state (Martinez and Kolter, 1997). These systems are regulated by several genes, in particular $\operatorname{axy}_{\mathrm{R}}$, a regulon dependent on the aforementioned SOS response and which codes for the gene Dps. Martinez and Kolter (1997) theorized that Dps is able to incur resistance to oxidative stress by initiating the cell to enter a starvation state, in which its metabolic systems are much less affected by environmental stresses. They found that cells lacking Dps had a four-fold higher number of single-strand DNA breaks than those that contained the intact gene when under a $2 \mathrm{mM} \mathrm{H}_{2} \mathrm{O}_{2}$ treatment. In addition, Dps-containing cells also exhibited a degree of protection at $\mathrm{H}_{2} \mathrm{O}_{2}$ concentrations of $100 \mathrm{mM}$, which readily degraded the DNA in Dps-lacking cells. Martinez and Kolter concluded that Dps is able to protect against oxidative stress by directly binding to DNA in order to prevent nicking, strand breaks, and point mutations. This theory remains unproven, however, and other theories as to the role of $D p s$ in the defense against oxygen radicals also exist.

Exposure to ultra-high pressure (UHP) is also thought to initiate the SOS response and thus the expression of the Dps protein via the induction of oxidative stress (Malone et al. 2006). Malone et al. tested the effects of a UHP treatment on the genetic response of E. coli O157:H7. A variety of E. coli strains were held at $500 \mathrm{MPa}$ for $1 \mathrm{~min}$ at $23^{\circ} \mathrm{C}$ and then analyzed by microarray. Upon analysis, it was found that the dps gene was significantly downregulated, perhaps because the main target of UHP is the cell membrane and not DNA damage. Malone et al. reasoned that the DNA-binding gene dps was down-regulated in order for the cell's DNA to have time to renature without the added difficulty of a bulky, bound protein. However, dps was still found to be vital to the survival of the cell when exposed to 
UHP. A dps null mutant was almost twice as sensitive to UHP as a wild type cell. The heat shock genes $i b p A$ and $i b p B$ were also analyzed, and interestingly, $i b p A$ expression increased almost two-fold while $i b p B$ expression remained unchanged. When these genes were replaced by null mutations, viability was only slightly decreased. This result may be due to the fact that, again, DNA is not the target of UHP-based inactivation and that protein denaturation may only be a minor result of UHP. Finally, the rpoS gene, which is necessary for entrance into the stationary phase, was found to have no change in expression upon analysis of the genetics of UHP treatment; however, mutant strains lacking rpoS were significantly less viable when exposed to UHP than wild type cells (Malone et al. 2006).

Resistance to extreme environmental stresses is clearly a result of many genes working in concert to allow the cell to withstand the stress and repair any damage that it may incur upon the cell's DNA. Microarray analysis has been performed many times to determine the roles of resistance genes for other stimuli; however, no analysis has yet been done to test the genes involved in resistance to electron beam radiation. Therefore, the objective of this study was to create a strain of E. coli $\mathrm{O} 157: \mathrm{H} 7$ that had become resistant to some stressful stimuli (in this case, e-beam radiation) by repeatedly exposing it to the stress at sub-lethal levels and to analyze the genome-wide effect on the stress response genes.

\section{MATERIALS \& METHODS}

Isolation of Strains

The ATCC strain used was reconstituted from a pellet of ATCC strain \#35150. Strain L4 was the result of a series of electron beam radiation treatments. The initial ATCC strain of E. coli O157:H7 grown in trypticase soy broth (TSB - Becton, Dickinson, and Company, Sparks, MD) overnight with shaking at $150 \mathrm{rpm}$ (C24 Incubator/Shaker, New Brunswick Scientific, Edison, NJ). A further inoculum of $2 \mathrm{~mL}$ of survivors was added to $38 \mathrm{~mL}$ of sterile TSB and grown overnight. A 5\% inoculum size was then added to a sample of ground beef purchased from a local 
grocery store and thawed overnight to $4^{\circ} \mathrm{C}$. The total mixture was incubated (Isotemp Incubator, Fisher Scientific, Pittsburgh, PA) at $35^{\circ} \mathrm{C}$ for 30 hours. Preliminary studies showed that the final microbial count for all samples reached approximately $10^{9}$ upon completion of incubation for 30 hours. Following incubation, 18 individual samples of approximately $10 \mathrm{~g}$ of inoculated beef were separately packaged into bags (Kapak SealPAK 4" by 6" pouches, Kapak Corporation, Minneapolis, MN), aerobically sealed (Kapak sealer, Kapak Corporation, Minneapolis, MN), and subjected to a dose of e-beam radiation ranging from 0 to $2.5 \mathrm{kGy}$ (See Treatment section of Chapter 2). Each bagged sample was spread evenly to a width of approximately $1 \mathrm{~mm}$ in order to ensure complete penetration of electron beams throughout the sample. Double bagging (Kapak SealPAK 6.5" by 8" pouches, Kapak Corporation, Minneapolis, MN) was utilized to ensure that no contamination occurred and samples were stored at $-80^{\circ} \mathrm{C}$ until shipment.

\section{Treatment}

Samples were packaged in a Styrofoam cooler containing dry ice to maintain freezing temperatures and maintain microbial populations without causing inactivation. Samples were shipped overnight to an e-beam processing facility (Sterigenics International, San Diego, CA). Once received at the facility, each sample was thawed to $4^{\circ} \mathrm{C}$ before undergoing treatment. Treatment consisted of exposure of microbes in triplicate to one-sided e-beam radiation in five increasing doses - 0 (control), $0.5 \mathrm{kGy}, 1.0 \mathrm{kGy}, 1.5 \mathrm{kGy}, 2.0 \mathrm{kGy}$, and $2.5 \mathrm{kGy}$ - for a total of 18

samples. Immediately following treatment, samples were stored in a $-80^{\circ} \mathrm{C}$ freezer. Samples were packaged in a Styrofoam cooler with dry ice to maintain freezing temperatures and shipped back to the Food Microbiology laboratory at West Virginia University and stored in a $-80^{\circ} \mathrm{C}$ freezer until analysis.

\section{Enumeration}

All 18 samples were thawed to $4^{\circ} \mathrm{C}$. Each sample was enumerated by placing $10 \mathrm{~g}$ of the e-beam treated sample using a sterile spatula into a sterile filter stomacher bag (Two-Chamber 
FILTRABAG, Fisher Scientific, Pittsburgh, PA). An aliquot of $90 \mathrm{ml}$ of dilutent (Butterfield phosphate buffer, Hardy Diagnostics, Santa Maria, CA) was aseptically added to the filter stomacher bag and the bag was placed into a stomacher (Bag Mixer 400, Interscience, St. Nom, France) for $2 \mathrm{~min}$. Further serial dilutions were aseptically made by taking $10 \mathrm{ml}$ of diluted sample and transferring it into a $90 \mathrm{ml}$ diluent bottle, followed by manual shaking to uniformly distribute survivors. An aliquot of $1 \mathrm{ml}$ of each serial dilution was pipetted onto a petrifilm plate (Petrifilm E. coli/Coliform Count Plate, 3M, St. Paul, MN) and spread by a petrifilm spreader. Plates were incubated at $35^{\circ} \mathrm{C}$ for $48 \mathrm{hr}$ using AOAC method 991.14. Only plates with 15-150 colonies were counted (Procedure adapted from Black and Jaczynski). Following enumeration, survivors from the highest e-beam dose were removed at random from the plates using a sterile loop and grown in $10 \mathrm{~mL}$ of sterile TSB with shaking $(150 \mathrm{rpm})$. A further inoculum of $2 \mathrm{~mL}$ of survivors was added to $38 \mathrm{~mL}$ of sterile TSB and grown overnight. These recovered microbes were then used as the inoculum for the next sample of ground beef and round of radiation. This process was repeated four times for a total of five exposures to increasing e-beam levels. Survivors of the fifth exposure to e-beam were isolated and grown in TSB and became strain L4.

Steps for Micro-array Analysis

Micro-array analysis was performed by first isolating total RNA from the bacteria (MasterPure RNA Purification Kit, Epicentre Biotechnologies, Madison, WI). From total RNA, we were able to isolate and purify mRNA (MICROBExpress Bacterial mRNA Purification Kit, Ambion, Austin, TX). Complementary DNA (cDNA) was then prepared using random hexamers. cDNA was then labeled using Cy3 and Cy5 dyes with incorporated dye swapping. Pre- and post-hybridization washes were done according to Corning Epoxide Coated Slides Instruction Manual (Corning Incorporated, Corning, NY) and all arrays were done manually overnight in a water bath at $42^{\circ} \mathrm{C}$ (Precision Analog Devises Microprocessor 
Controlled 280 Series Water Bath, MA). For a complete description of protocols, please see Appendix A.

\section{RESULTS \& DISCUSSION}

After 15 attempts at microarray analysis, the project was abandoned due to lack of time, success of hybridization, and reproducible results. Of the 15 attempts, only two produced quantitatable results (Figure 1). This technology is very delicate and requires near-perfect conditions to be successful; unfortunately, due to unknown complications, the experiment was not successful. Hybridization was always successful for one dye only, regardless of dye swapping, while the other dye always exhibited an overabundance of background hybridization with very little clean, quantitatable hybridization to probes. With additional time and careful work, we are sure that the project will be successful, possibly resulting in a patent issuance for the rapid and accurate detection of radio-resistant strains of E. coli O157:H7.

\section{ACKNOWLEDGEMENTS}

I would like to thank Dr. Anthony Cornish and laboratory technician Troy Locke of the University of Alberta, Canada for providing micro-array chips, as well as advice and encouragement. I would also like to thank Raghuveer Ramachandran, Brandon Lingenfelter, and Ida Holaskova for their guidance in the laboratory and vast knowledge of protocols and micro-array techniques. 


\section{REFERENCES}

Altekruse SF, Cohen ML, and Swerdlow DL. 1997. Emerging foodborne diseases. Emerging Infectious Diseases 3(3): 285-293.

Bell, C., Kyriakides, A., 1999. E. coli, a practical approach to the organism and its control in foods. Blackwell Science, London, pp 200.

Black, J.L., Jaczynski, J., 2007b. Effect of water activity on inactivation kinetics of Escherichia coli $\mathrm{O} 157: \mathrm{H} 7$ by electron beam in ground beef, chicken breast meat, and trout fillets. International Journal of Food Science and Techonology. In Press doi:10.1111/j.13652621.2006.01480.

Cheville AM, Arnold KW, Buchrieser C, Cheng C-M, and Kaspar CW. 1996. rpoS regulation of acid, heat, and salt tolerance in Escherichia coli O157:H7. Applied and Environmental Microbiology 62(5): 1822-1824.

Courcelle J, Khodursky A, Peter B, Brown PO, and Hanawalt PC. 2001. Comparative gene expression profiles following UV exposure in wild-type and SOS-deficient Escherichia coli. Genetics 158: 41-64.

Dowd SE and Ishizaki H. 2006. Microarray based comparison of two Escherichia coli O157:H7 lineages. BMC Microbiology 6:30-41.

Environmental Protection Agency. 2007. Food Irradiation. www.epa.gove/radiation/sources/food irrad.htm.

Khil PP and Camerini-Otero RD. 2002. Over 1000 genes are involved in the DNA damage response of Escherichia coli. Molecular Microbiology 44(1): 89-105.

Levanduski L and Jaczynski J. 2007. Increased Resistance of Escherichia coli O157:H7 to electron beam following repetitive irradiation at sub-lethal doses. 
Little JW and Mount DW. 1982. The SOS regulatory system of Escherichia coli. Cell 29:11-22.

Malone AS, Chung Y-K, Yousef AE. 2006. Genes of Escherichia coli O157:H7 that are involved in high-pressure resistance. Applied and Environmental Microbiology 72(4): 2661-2671.

Martinez A and Kolter R. 1997. Protection of DNA during oxidative stress by the nonspecific DNA-binding protein Dps. J Bacteriol 179(16): 5188-5194.

Tauxe RV. 2001. Food safety and irradiation: protecting the public from foodborne infections. Emerging Infectious Diseases 7(3) Suppl:516-521.

Tauxe RV. 2002. Emerging foodborne pathogens. International Journal of Food Microbiology 78: 31-41.

Thomas JG and Baneyx F. 1998. Roles of the Escherichia coli small heat shock proteins $\mathrm{IbpA}$ and IbpB in thermal stress management: comparison with ClpA, ClpB, and HtpB in vivo. J Bacteriol 180(19): 5165-5172.

World Health Organization. Accessed on April 25, 2007. http://www.who.int/mediacentre/factsheets/fs125/en/ 

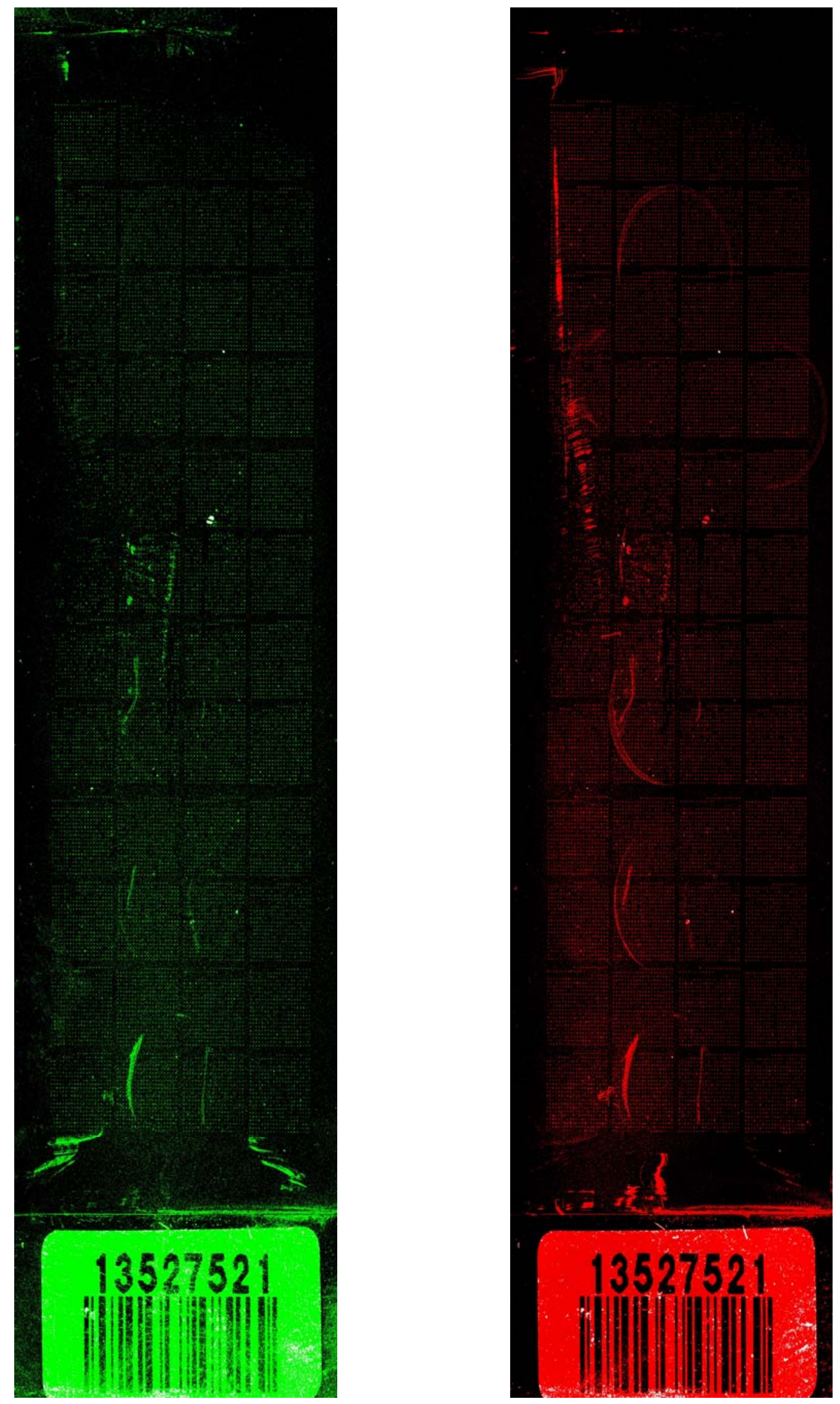


\section{Figure 1.}

The image on the left represents a scan of the ATCC strain labeled with Cyanine 3 dye obtained June 26, 2007. The image on the right represents a scan of the L4 strain labeled with Cyanine 5 dye obtained on June 26, 2007. These images were scanned from the same microarray chip and represent quantitatable images from which statistically significant data can be obtained.

\section{Figure 2.}

The image on the left represents a scan of the ATCC strain labeled with Cyanine 3 dye obtained June 15, 2007. The image on the right represents a scan of the L4 strain labeled with Cyanine 5 dye obtained on June 15, 2007. These images were scanned from the same microarray chip, but hybridization was poor for the Cyanine 3 dye and contained too much background noise. Therefore, these images represent data that is not quantitatable and thus not of use for the purpose of obtaining statistically significant data. 

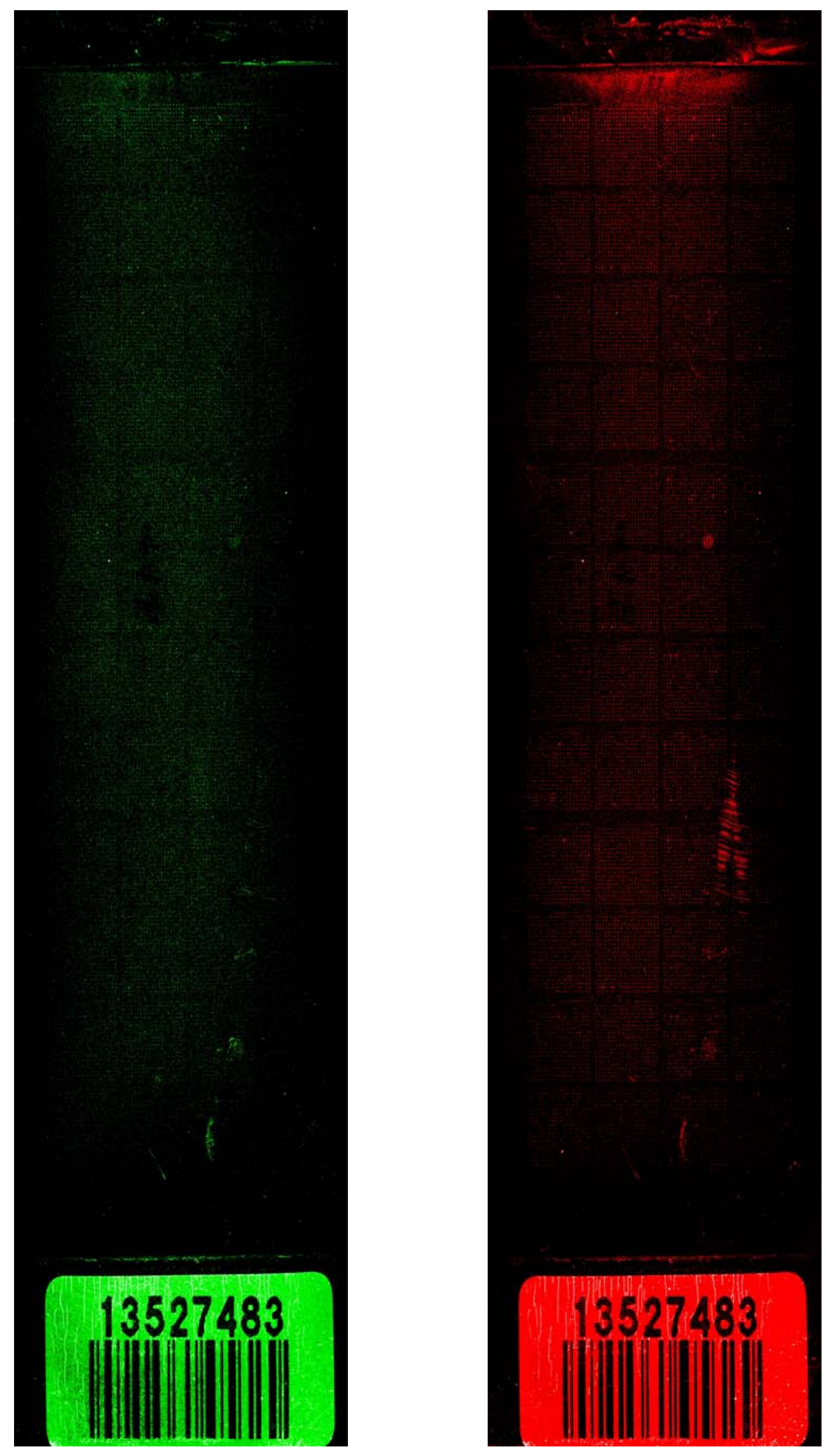


\section{APPENDIX A: STEPS FOR MICROARRAY ANALYSIS}

1. ISOLATION OF TOTAL RNA (adapted from the protocol for MasterPure RNA Purification kit, Epicentre Biotechnologies, Madison, WI)

\section{a. Cell Samples}

i. Separate total volume E. coli into separate $10 \mathrm{~mL}$ conical tubes

ii. Dilute $1 \mu \mathrm{l}$ of $50 \mu \mathrm{g} / \mu \mathrm{l}$ Proteinase K into $300 \mu \mathrm{l}$ Tissue and Cell Lysis Solution for each sample

iii. Pellet cells by centrifugation (0.1-0.5 $\mathrm{ml}$ of and overnight culture of $E$. coli) and discard supernatant, leaving approx $25 \mu \mathrm{l}$ of liquid

iv. Vortex mix $10 \mathrm{~s}$ to resuspend cell pellet

v. Add $300 \mu \mathrm{l}$ of Tissue and Cell Lysis Solution containing the Proteinase $\mathrm{K}$ and mix thoroughly

vi. Incubate at $65^{\circ} \mathrm{C}$ for $15 \mathrm{~min}$; vortex mix every $5 \mathrm{~min}$ (may appear foamy)

vii. Place samples on ice for 3-5 min and then proceed with RNA precipitation

\section{b. Precipitation of Total RNA}

i. Add $175 \mu$ l of MPC Protein Precipitation Reagent to $300 \mu$ l of lysed sample and vortex mix vigorously for $10 \mathrm{~s}$

ii. Pellet the debris by centrifugation for $10 \mathrm{~min}$ at $>10,000 \mathrm{xg}$ in a microfuge

iii. Transfer the supernatant to a clean micro centrifuge tube and discard pellet

iv. Add $500 \mu \mathrm{l}$ of isopropanol to recovered supernatant

v. Invert the tube several (30-40) times

vi. Pellet RNA by centrifugation at $4^{\circ} \mathrm{C}$ for $10 \mathrm{~min}$ in a micro centrifuge

vii. Carefully pour off the isopropanol without dislodging the RNA pellet.

c. Removal of Contaminating DNA from RNA Preparations, freeze at $80 C$

i. Remove all of the residual isopropanol with a pipette

ii. Prepare $200 \mu \mathrm{l}$ of DNase I solution for each sample by diluting $5 \mu \mathrm{l}$ of RNase-free DNase I up to $200 \mu \mathrm{l}$ with $1 \mathrm{X}$ DNase Buffer

iii. Completely resuspend the nucleic acid pellet in $200 \mu$ of DNase I solution

iv. Incubate at $37^{\circ} \mathrm{C}$ for $10 \mathrm{~min}$. Additional incubation up to $30 \mathrm{~min}$ may be necessary to remove all contaminating DNA

v. Add $200 \mu \mathrm{l}$ of $2 \mathrm{X} \mathrm{T}$ and C Lysis Solution; vortex mix for $5 \mathrm{~s}$

vi. Add $200 \mu \mathrm{l}$ of MPC Protein Precipitation Reagent; vortex mix $10 \mathrm{~s}$; place on ice 3-5 min

vii. Pellet the debris by centrifugation for $10 \mathrm{~min}$ at $>10,000 \mathrm{~g}$ in a microfuge (Beckman Coulter, Microfuge R Centrifuge, Fullerton, Ca)

viii. Transfer the supernatant containing the RNA into a clean micro centrifuge tube and discard the pellet

ix. Add $500 \mu \mathrm{l}$ of isopropanol to the supernatant 
x. Invert the tube 30-40 times

xi. Pellet the purified RNA by centrifugation at $4^{\circ} \mathrm{C}$ for $10 \mathrm{~min}$ in a micro centrifuge

xii. Carefully pour off isopropanol without dislodging the pellet

xiii. Rinse twice with $75 \%$ ethanol, being careful to not dislodge the pellet. Centrifuge briefly if the pellet is dislodged. Remove all residual ethanol with a pipette.

xiv. Resuspend the RNA in $35 \mu$ l of TE buffer

xv. Add $1 \mu \mathrm{l}$ of ScriptGuard RNase Inhibitor. Final volume: $36 \mu 1$

\section{ISOLATION OF mRNA USING MICROBexpress BACTERIA MRNA} PURIFICATION KIT (AM1905, Ambion, Austin, TX)

a. $\boldsymbol{R} \mathbf{N A}$ Precipitation Instruction

i. Precipitate the RNA by adding the following and mixing well:

1. $0.1(3.6 \mu \mathrm{l})$ volume $5 \mathrm{M}$ ammonium acetate or $3 \mathrm{M}$ sodium acetate

2. (optional) $5 \mu \mathrm{g}(1 \mu \mathrm{l})$ glycogen

3. $2.5-3(\sim 100 \mu \mathrm{l})$ volumes $100 \%$ ethanol

ii. Leave the mixture at $-20^{\circ} \mathbf{C}$ overnight, or quick-freeze it in a $-80^{\circ} \mathrm{C}$ freezer for $30 \mathrm{~min}$

iii. Recover the RNA by centrifugation at $>12,000 \mathrm{x}$ f for $30 \mathrm{~min}$ at $4^{\circ} \mathrm{C}$

iv. Carefully remove and discard supernatant. The RNA pellet may not adhere tightly to the walls of the tubes, so remove the supernatant by gentle aspiration with a fine-tipped pipette

v. Centrifuge the tube briefly a second time, and aspirate any additional fluid that collects with a fine-tipped pipette

vi. Add $1 \mathrm{ml}$ ice-cold $70 \%$ ethanol and vortex tube

vii. Re-pellet the RNA by centrifugation for $10 \mathrm{~min}$ at $4^{\circ} \mathrm{C}$. Remove the supernatant carefully as described in steps (iv) and (v)

viii. Repeat steps (vi) and (vii)

ix. Dissolve the RNA in $\sim 15 \mu \mathrm{l}$ TE buffer

x. Check mRNA yield in spectrophotometer (NanoDrop ND-1000 Spectrophotometer, Wilmington, De)

b. Anneal RNA and Capture Oligonucleotide Mix (NOTE: the most accurate way to evaluate the mRNA enrichment of samples at the end of the procedure is to include a mock reaction sample where the Capture Oligo Mix is not included, but otherwise the sample is subjected to the entire MICROBExpress procedure.)

i. Pipette $200 \mu \mathrm{l}$ Binding Buffer into a PCR tube

ii. Add total RNA (2-10 $\mu \mathrm{g}$ RNA in a maximum volume of $15 \mu \mathrm{l})$ to Binding Buffer (amount of total RNA can be calculated from spec reading)

iii. Close the tube and tap or vortex gently

iv. Add $4 \mu \mathrm{l}$ of Capture Oligo Mix to the RNA in Binding Buffer (only 2 out of 3 tubes if following mock reaction protocol) 
v. Incubate mixture at $70^{\circ} \mathrm{C}$ for $10 \mathrm{~min}$ to denature secondary structure in RNA, including the $16 \mathrm{~S}$ and $23 \mathrm{~S} \mathrm{rRNAs}$. This heat denaturation helps to facilitate maximal hybridization of rRNAs to the capture oligonucleotides.

vi. Anneal at $37^{\circ} \mathrm{C}$ for $15 \mathrm{~min}$. This allows the capture oligonucleotides to hybridize to homologous regions of the $16 \mathrm{~S}$ and $23 \mathrm{~S}$ rRNAs. The binding buffer is optimized to function specifically and efficiently at this temp. Prepare the Oligo MagBeads as described in the next section during this incubation.

\section{c. Prepare the Oligo MagBeads}

i. Withdraw $50 \mu \mathrm{l}$ Oligo MagBeads per sample to a $1.5 \mathrm{ml}$ tube

ii. Capture the Oligo MagBeads by placing the tube on a magnetic stand (Single Place Magnetic Stand, Ambion, Austin, TX) for roughly $3 \mathrm{~min}$ and carefully remove the supernatant by aspiration and discard

iii. Wash the Oligo MagBeads with an equal volume of Nuclease-free water

1. Add $50 \mu \mathrm{l}$ Nuclease-free water to the captured Oligo MagBeads

2. Remove the tube from the magnetic stand and resuspend the beads by brief, gentle vortexing

3. Recapture the Oligo MagBeads with a magnetic stand and carefully aspirate and discard the water, leaving the beads in the tube

iv. Equilibrate the Oligo MagBeads with an equal volume of Binding Buffer

1. Add $50 \mu \mathrm{l}$ Binding Buffer to the captured Oligo MagBeads

2. Remove the tube from the magnetic stand and resuspend the beads by brief, gentle vortexing

3. Recapture the Oligo MagBeads with a magnetic stand and carefully aspirate and discard the Binding Buffer, leaving the beads in the tube

v. Resuspend the Oligo MagBeads in an equal volume of Binding Buffer and bring the slurry to $37^{\circ} \mathrm{C}$ (Select Heatblock, VWR Scientific Products, Seattle, Wa)

1. Repeat steps (iv) $1-2$

2. Place the Oligo MagBead slurry in a $37^{\circ} \mathrm{C}$ incubator and allow the temp to equilibrate to $37^{\circ} \mathrm{C}$ before proceeding

\section{d. Capture the rRNA and Recover the Enriched $m \boldsymbol{R N A}$}

i. Heat the Wash Solution to $37^{\circ} \mathrm{C}$ to be used in step (iv)

ii. Add $50 \mu \mathrm{l}$ prepared Oligo MagBeads to the RNA/Capture Oligo Mix and incubate at $37^{\circ} \mathrm{C}$ for $15 \mathrm{~min}$

1. Gently vortex the tube of washed and equilibrated Oligo MagBeads from step c.v. to resuspend them and add $50 \mu \mathrm{l}$ of Oligo MagBeads to the RNA/Capture Oligo Mix

2. Very gently vortex or tap the tube to mix and microfuge very briefly to get the mixture to the bottom of the tube 
3. Incubate at $37^{\circ} \mathrm{C}$ for $15 \mathrm{~min}$. During this step, the oligonucleotide sequence on the Oligo MagBeads anneals to the Capture Oligonucleotides and the Capture Oligonucleotides remain hybridized to the $16 \mathrm{~S}$ and $23 \mathrm{~S}$ rRNAs.

iii. Capture the Oligo MagBeads and move the mRNA to a Collection Tube

1. Capture the Oligo MagBeads by placing the tube on the Magnetic Stand. Leave the tube on the stand until all of the Oligo MagBeads are arranged inside the tube near the magnet $(\sim 3 \mathrm{~min})$

2. Aspirate the supernatant which contains the enriched mRNA, being careful not to dislodge the Oligo MagBeads. Transfer it to a new collection tube on ice.

iv. Recover any remaining mRNA from the Oligo MagBeads by washing

1. Add $100 \mu \mathrm{l}$ Wash Solution that has been pre-warmed to $37^{\circ} \mathrm{C}$ to the captured Oligo MagBeads.

2. Remove the tube from the magnetic stand and resuspend the beads by brief, gentle vortexing in the $37^{\circ} \mathrm{C}$ Wash Solution. This wash step recovers mRNAs that were inadvertently trapped in the rRNA:Capture Oligonucleotide hybrids

3. Recapture the Oligo MagBeads and carefully recover the supernatant. Pool this supernatant with the RNA already in the collection tube and proceed immediately to the precipitation described next

\section{e. Precipitate and Resuspend the Enriched $m \boldsymbol{R N A}$}

i. Ethanol precipitate the enriched mRNA

1. Add the following to the pooled mRNA (the volume should be $\sim 350 \mu \mathrm{l})$, and briefly vortex to mix:
a. $1 / 10^{\text {th }}$ volume $3 \mathrm{M}$ Sodium Acetate $(35 \mu \mathrm{l})$
b. $1 / 50^{\text {th }}$ volume Glycogen $(5 \mathrm{mg} / \mathrm{ml})$, and final concentration will be $100 \mu \mathrm{g} / \mathrm{ml}(7 \mu \mathrm{l})$

2. Add 3 volumes ice cold $100 \%$ ethanol $(1175 \mu \mathrm{l})$ and vortex to mix

3. Precipitate at $-20^{\circ} \mathrm{C}$ for at least $1 \mathrm{hr}$

4. Centrifuge for $30 \mathrm{~min}$ at $13,000 \mathrm{rpm}$ and carefully decant and discard supernatant

5. Do a $70 \%$ ethanol wash as follows:
a. Add $750 \mu$ lice cold $70 \%$ ethanol and vortex
b. Centrifuge for $5 \mathrm{~min}$ at $13,000 \mathrm{rpm}$. Discard supernatant

6. Do a second $70 \%$ ethanol wash as in step 5

7. Briefly re-spin the tube after discarding the second $70 \%$ ethanol wash. Carefully remove any remaining supernatant with a pipetter, being careful not to dislodge the pellet. 
8. Air dry the pellet for $5 \mathrm{~min}$. DO NOT air dry pellet for more than 5 min.

ii. Resuspend the enriched $\mathrm{mRNA}$ in an appropriate buffer

1. Resuspend the RNA pellet in $25 \mu \mathrm{l}$ TE buffer

2. Rehydrate the RNA for $15 \mathrm{~min}$ at room temp. Vortex the sample vigorously if necessary to resuspend RNA. Collect by brief centrifugation

iii. Remove residual Oligo MagBeads if necessary

1. To remove beads, put the tube on the magnetic stand for $\sim 3$ min and move the enriched mRNA solution to a new RNasefree tube. Enriched $\mathbf{m R N A}$ yield from $10 \mu \mathrm{g}$ of high quality total RNA is typically 1-2.5 $\mu \mathrm{g}$

iv. Run a spectrophotometer analysis of Nucleic Acid using a $1 \mu \mathrm{L}$ sample of RNA. Blank spec once with water. Change setting to RNA, blank again with water. Measure sample. This will tell you how much RNA you will need to get $\mathrm{X} \mu \mathrm{g}$ of total RNA

\section{3. cDNA SYNTHESIS $(3 \mathrm{hrs})$, freeze at $-80^{\circ} \mathrm{C}$}

a. In a PCR tube, combine $\sim 11 \mu \mathrm{l}$ mRNA $+2 \mu \mathrm{ldNTP}+2 \mu \mathrm{l}$ Random Hexamers (stored at $-20^{\circ} \mathrm{C}$ ). Incubate at $65^{\circ} \mathrm{C}$ for $10 \mathrm{~min}$ (MJ Research, PTC-200 Peltier Thermal Cylcer, Waltham, Ma) then immediately quench on ice for at least $1 \mathrm{~min}$.

b. Add the following to each tube: $6 \mu \mathrm{l} 5 \mathrm{x} \mathrm{S}$ Buffer $+1.5 \mu \mathrm{l} 0.1 \mathrm{~m} \mathrm{DTT}+2 \mu \mathrm{l}$ SuperScript III RT $+5.5 \mu \mathrm{l}$ DEPC-treated water. Incubate at $42^{\circ} \mathrm{C}$ in PCR machine for at least 2 hours, then at $70^{\circ} \mathrm{C}$ for $10-15$ min. Total volume $=$ $30 \mu$ l.

4. PREP FOR MICROARRAY $(\sim 5.5 \mathrm{hrs})$

a. Alkaline Hydrolysis and Neutralization

i. Add $15 \mu \mathrm{l}$ of $1 \mathrm{M} \mathrm{NaOH}$ to each reaction tube to hydrolyze the RNA

ii. Mix thoroughly and incubate tubes at $70^{\circ} \mathrm{C}$ for $10 \mathrm{~min}$

iii. Add $15 \mu$ of $1 \mathrm{~N} \mathrm{HCl}$ to neutralize the $\mathrm{pH}$ and mix gently

b. Ethanol precipitation of aminoallyl labeled cDNA

i. Transfer the cDNA from the PCR tubes to $1.5 \mathrm{ml}$ tubes

ii. Add $4 \mu \mathrm{l}$ of $3 \mathrm{M}$ Sodium Acetate $(\mathrm{pH} 5.2)$ and $85 \mu \mathrm{l}$ of ice-cold $100 \%$ ethanol

iii. Keep at $-20^{\circ} \mathrm{C}$ for at least 30 min to precipitate DNA (or precipitate overnight for best results)

iv. Spin at max speed $(20,800 \mathrm{RCF})$ for $20 \mathrm{~min}$ at $4^{\circ} \mathrm{C}$

v. Wash cDNA pellets with $500 \mu \mathrm{l}$ of $70 \%$ ice-cold ethanol

vi. Quick spin pellets ( 2-3 min) and air dry. Resuspend DNA in $25 \mu$ of $0.1 \mathrm{M} \mathrm{Na} 2 \mathrm{CO} 3(\mathrm{pH}$ )

c. Coupling Aminoallyl cDNA to Cy Dyes

i. Add $4.5 \mu \mathrm{l} \mathrm{Cy3}$ (red) dye to ATCC cDNA 
ii. Add $4.5 \mu \mathrm{l} \mathrm{Cy5}$ (blue) dye to L4 cDNA

iii. Wrap all reaction tubes in foil and incubate for 1-2 hours in the dark at room temp

d. Start Hybridization Station Protocol and heat up the EB Buffer at 70 $\boldsymbol{C}$ in PCR machine. $\sim 120 \mu \mathrm{l}$ per tube

e.

Purification of labeled cDNA using QIAquick PCR purification kit (Qiagen Sciences, Maryland), freeze at $-80^{\circ} \mathrm{C}$

i. Add $20 \mu \mathrm{l}$ water to each tube for a total volume of $50 \mu \mathrm{l}$

ii. Add $250 \mu$ of PB Buffer (Qiagen supplied) and mix briefly

iii. Place a QIA quick spin column in a $2 \mathrm{ml}$ collection tube

iv. Apply the sample to the column and centrifuge at $13,000 \mathrm{rpm}$ for 1 $\min$

v. Discard flow-through and place QIA quick column back into same tube

vi. Add $750 \mu \mathrm{l}$ of PE Buffer to column and centrifuge briefly at 13,000 rpm for $1 \mathrm{~min}$

vii. Empty collection tube and centrifuge column for additional $1 \mathrm{~min}$ at max speed

viii. Place column in a clean $1.5 \mathrm{ml}$ microfuge tube (cut the lid off)

ix. Carefully add $50 \mu \mathrm{l}$ of EB Buffer (pre-warmed to $70^{\circ} \mathrm{C}$ ) to the center of the column membrane. Centrifuge at 13,000 rpm for $1 \mathrm{~min}$ to elute (collect by dissolving) the DNA. Repeat this elution step with an additional $50 \mu \mathrm{EB}$ buffer. The final elution volume should be $\sim 100$ $\mu l$.

f. Pre-Hybridization of slides to block unused surface of the slide an remove loosely bound probe DNA (as described in Corning Epoxide Coated Slides Instruction Manual - Corning Incorp., Corning, NY. Slides were purchased from Dr. Anthony Cornish at the University of Alberta, Alberta, Canada.)

i. Prepare prehybridization solution consisting of $5 \times$ SSC $(12.5 \mathrm{~mL} 20 x$ SSC), $0.1 \%$ SDS (0.25 mL 20\% SDS), and $0.1 \mathrm{mg} / \mathrm{ml} \mathrm{BSA} \mathrm{(5} \mathrm{mg} \mathrm{BSA).}$ Combine ingredients in water $(37.25 \mathrm{~mL})$. Using Coplin jars, use only $50 \mathrm{~mL}$ of solution per step.

ii. Warm prehybridization solution to $42^{\circ} \mathrm{C}$

iii. Immerse arrays in prehybridization solution and incubate at $42^{\circ} \mathrm{C}$ for 45-60 min

iv. Transfer prehybridized arrays to $0.1 \times$ SSC and incubate at ambient temperature $\left(22-25^{\circ} \mathrm{C}\right)$ for $5 \mathrm{~min}$

v. Repeat step (iv) twice, for a total of 3 washes

vi. Transfer arrays to purified water and incubate at ambient temperature for 30 seconds 
vii. Dry arrays by centrifugation at $1,600 \mathrm{x}$ g for 2 min. Keep arrays in a dust-free environment while completing the preparation of the hybridization solution.

\section{g. Concentrate labeled cDNA samples using vacufuge}

i. Place eluted DNA in microfuge into the vacufuge (Eppendorf Vacufuge, Hamburg, Germany) and "dry" it (concentrate it) by vacuum at $60^{\circ} \mathrm{C}$ without spinning (Brake + Temp + Start) until only $\sim 10-20 \mu$ l remain $(\sim 30-45 \mathrm{~min})$

ii. Rehydrate with $50 \mu$ l hybridization solution (Ambion Slide 3 Hybridization Solution, Ambion, Austin, TX - stored at $4^{\circ} \mathrm{C}$ ) for each tube. Pipette up and down gently to ensure DNA does not stick to membrane. (Should have a total of $80-90 \mu$ for manual hybridization)

iii. Heat at $42^{\circ} \mathrm{C}$ for $5-10 \mathrm{~min}$

iv. Vortex and spin down

v. Pool the two samples into one PCR tube

vi. Heat to $95^{\circ} \mathrm{C}$ for $5 \mathrm{~min}$ in PCR machine. Sample may remain at $95^{\circ} \mathrm{C}$ longer if bubbles remain in solution

5. HYBRIDIZATION (for manual hybridization only)

a. Place one drop of water in each hole at either end of the hybridization chamber. Line the bottom of the chamber with water to prevent the array from drying out overnight.

b. Load labeled cDNA samples combined with hybridization solution into hybridization chamber

c. Hybridize overnight (12-16 hrs) in a water bath (Precision Analog Devises Microprocessor Controlled 280 Series Water Bath, Ma)at $42^{\circ} \mathrm{C}$ followed by posthybridization washing

d. Turn on microarray scanner (ScanArray Lite Microarray Scanner, Perkin Elmer, Downers Grove, Il) 15 minutes before hybridization is finished to preheat lasers

\section{POSTHYBRIDIZATION WASHES}

a. Immerse arrays in $2 \times \mathrm{SSC}, 0.1 \%$ SDS at $42^{\circ} \mathrm{C}$ until the cover glass moves freely away from the slide

b. Transfer arrays to $2 \times \mathrm{SSC}, 0.1 \% \mathrm{SDS}$ at $42^{\circ} \mathrm{C}$ for $5 \mathrm{~min}$

c. Transfer arrays to $1 \times$ SSC at room temperature for $2 \mathrm{~min}$

d. Repeat step c

e. Transfer arrays to $0.1 \times \mathrm{SSC}$ at room temperature for $1 \mathrm{~min}$

f. Repeat step e

g. Dry array by centrifugation at $1600 \mathrm{~g}$ for $2 \mathrm{~min}$

7. SCANNING THE SLIDE (Scan Array Lite, Microarray Scanner, Perkin Elmer)

a. Insert slide with bar code side facing up. Hit SCAN button. Run EasyScan at $10 \mathrm{pm}$. Scan takes $\sim 30$ minutes.

b. Adjust palette on right lower corner. Cy3 appears green, Cy5 appears red. 
c. For each dye, adjust black threshold $\sim 360$. Full color, $3 \times 3$ median to apply filter 